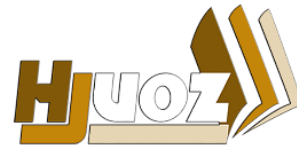

hjuoz.uoz.edu.krd p-ISSN: $2410-7557$
كَّوارا زانستيّن مروّقايه تى يا زانكوّيا زاخوّ

مجلة العلوم الانسانية لجامعة زاخو

Humanities Journal of University of Zakho (HJUOZ)

Vol. 5, No. 2, pp. 336-352, June-2017

\title{
الأقباط ودورهم السياسي في مصر 1866-1918
}

محمد داخل كريم السعدي و إطلال سالم حنا

قسم التاريخ، كلية التربية، جامعة الحمدانية، جمهورية مصر العربية.

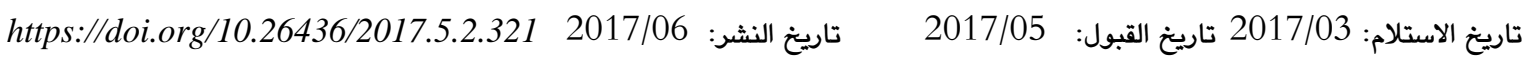

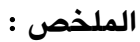

الاقباط من المكونات الاجتماعية المهمة التي يتشكل منها الشعب المصري ، وهم من المكونات الاصيلة التي لها تاريخ وجذور تمتد مع عمق الحضارة المصرية ، ولان ارض مصر جمع فيها التاريخ والحضارة والاديان فقد كانت دراسة الاقباط من الاهمية بمكان لتسليط

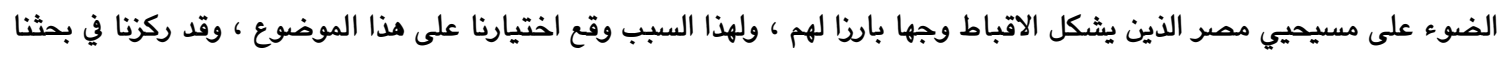
على الجانب السياسي لدود الاقباط في مصر لما له من اهمية كبيرة في بيان طبيعة المجتمع المصري المتوحد تحت راية المواطنة والولاء للوطن من خلال ما عرضناه في ثنايا البحث من وجود تمثيل حقيقي للاقباط في المواقع الادارية والسياسية ل.

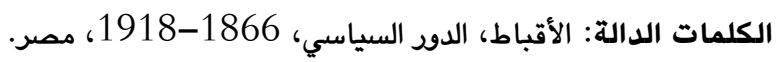

المهمة برزت ردود فعل مختلفة ومتباينة للأقباط يذكرها المؤرخ القبطي ويصا بأنهم "أصيبوا بالرعب" جراء ذلك (9). بينما يذهب عدد من المؤرخين الانكليز ويحكم كونهم مواطنين بريطانيين الى التقليل من مدى تقبل الاقباط للخدمة العسكرية ووجدوا

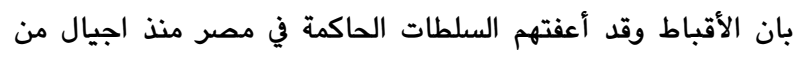
الخمة العسكرية رأوا من لائحة سعيد تجاههم ودعوتهم الى حمل السلاح عملا ملتويا يهدف سعيد من ورائه اضطهادهم وذكر مؤرخان انكليزيان

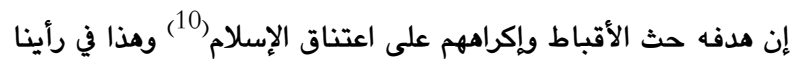

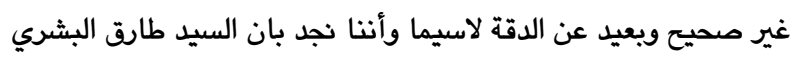

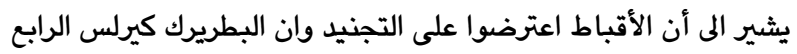

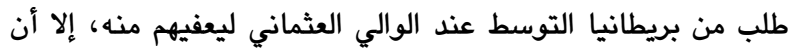

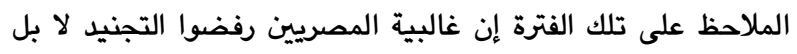
عملوا على الفرار منه (11)، ويهذا يكون المصريين كافة عارضوا

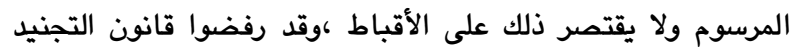

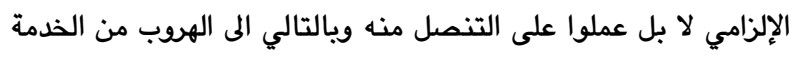

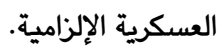

\section{2.عهد الخديوي إسماعيل (1879-1863).}

شهـ عهد الخديوي إسماعيل اندماجا كاملا بين المسلمين والأقباط

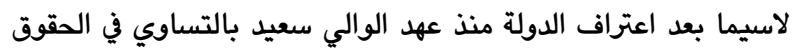

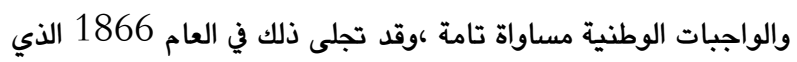

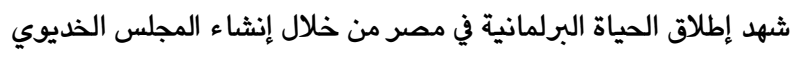
او مجلس شورى النواب (استشاري). ووفقا لتلك الحياة الديمقراطية

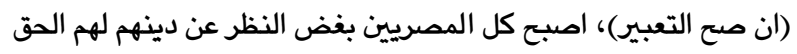

في التمتع بالحقوق السياسية، والترشيح الى هذا المجلس (12)

\section{1.تمهيد}

لم يندمج الأقباط(1) اندماجا كاملا في الحياة السياسية في مصر ولم يكن لهم حضورا واسعا إلا مع ميلاد الدولة الحديثة والمجتمع المدني الذي بدء من عصر محمد علي (1848-1805) وتأسيسه للدولة المدنية الحديثة في البلاد (2).

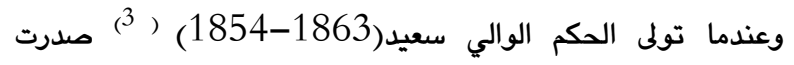

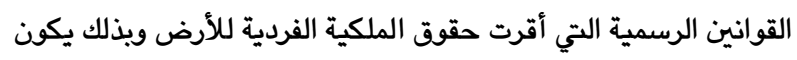

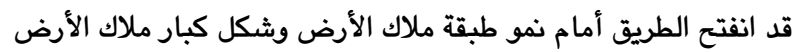

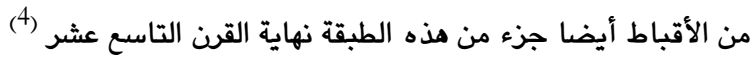

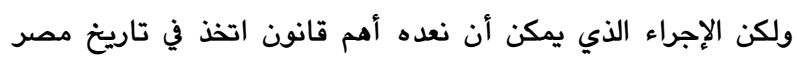
الحديث هو المساواة بين جميع أبناء الوطن بغض النظر عن ديانتهم الأن النداء

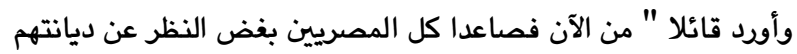

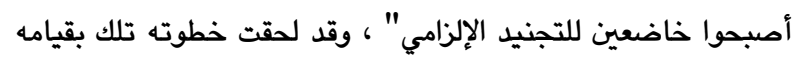

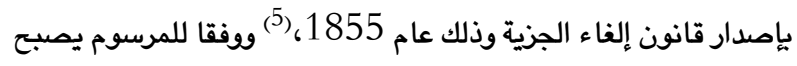

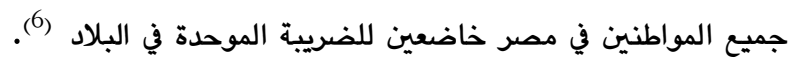
ويعد أن تم إصدار خط شريف ممايون عام 1856 من قبل السلطان

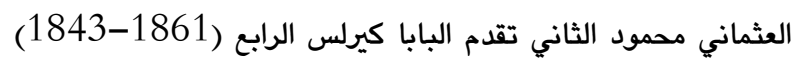

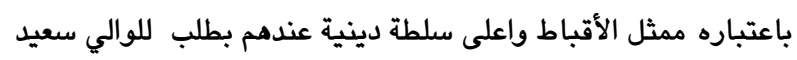

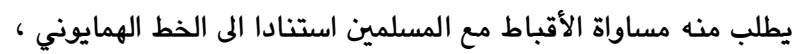

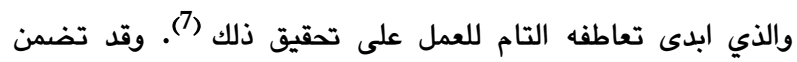
المرسوم الهمايوني المساواة للحقوق والواجبات بين المسلمين

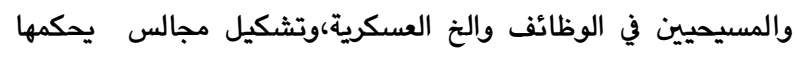
رجال الدين والعلمانيين تكون خاصة بالأمور الإدارية والمالية، فضلا الراليال عن تقديم الرخص لبناء الكنائس وغيرها(8)، على اثر تلك التطورات 
بمصر كما انها الخطوة التي بدا الأقباط من خلالها المشاركة بالحركة الوطنية ويناء الدولة وقرر الخديوي مشاركتهم في المجلس كمواطنين مصريين لهم حق الترشيح وفقا للمادة الثانية من اللائحة الأساسية

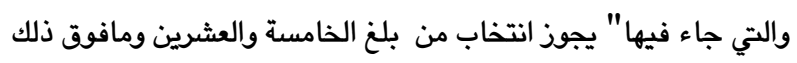
بشرط ان يكون موصوفا بالرشد والكمال وان يكون من الاثخاص به المعلومين عند الحكومة بانه من الاهالي التابعين لها ومن اولاد الوطن

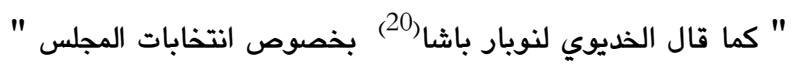
عندنا اقباط ايضا بين المنتخبين وقد فتحنا الباب للمسلمين والاقباط بدون تمييز (21). امتم الخديوي إسماعيل بالأقباط لتحسين صورته أمام العالم الخارجي،وليجعل الجميع متساون أمام القانون وكان يريد أن يمحو

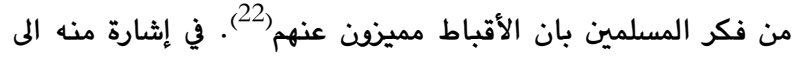
قانون التجنيد الإلزامي والذي كان يعفيهم من الخدمة العسكرية ولعدة

أجيال وهذا ما كان يجعل المسلمون يعتبونهم مختلفون عنهم . اقترح ميخائيل اثناسيوس في جلسة مجلس شورى النواب الأولى في 25 تشرين الثاني 1866 ،والذي فرض منذ عهد محمد علي إلغاء

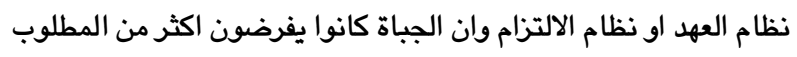
على الفلاحين وفي حال عدم بيع المحاصيل الزراعية يقوم الفلاح بسداد ذلك من دينه الخاص وهذا كان يستغله الملتزم وقد وافق الأعضاء على

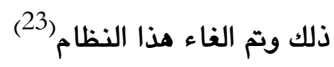
كما اقترح ايضا في الجلسة نفسها النائب ابو العز مقترح ايجاد مكاتب لتعليم الاهالي القراءة والكتابة واقترح اثناسيوس ان انشائها للتعليم والتعلم ليشمل الجميع وان تعليم الاقباط غير تعليم المسلمين لاسيما

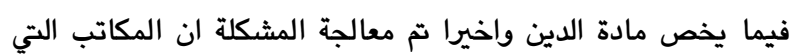

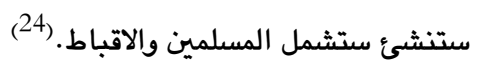
ويكتب احد المؤرخين بأنه" اذا كان الفضل يعود للخديوي إسماعيل في إنشاء أول مجلس نيابي في مصر الحديثة فان الأقباط كانوا من ورائه يطلبون هذا الطلب ويلحون فيه ويبتهجون لتحقيقه وإذا كتب لمصر يوما ان تؤرخ تاريخها الدستوري وتسجل للأبطال الذين ساهموا في الثورة،على استبداد الخديوي إسماعيل فان أسماء ميخائيل عبد السيد وجرجس ميلاد يجب ان تكون في مقدمة هذه الأسماء،فقد كانت إسماء جريدتهم هي التي عالجت شؤون مصر من وجهة نظر مصرية بحتة متخطية جميع الصعاب الرسمية من انذار وتعطيل فتحدثت عن مساؤى الحاشية والوزارة النوبارية معا وهاجمت الاجانب معا ووزيرهم وشجعت مجلس النواب... وامدت رجاله بالراي السديد وناقشت اموره الفقهية كواجب انتخاب رئيسه لاتعيينه وحق المجلس في فرض الضرائب ومسؤولية الوزارة امامه" وغيرها(25)

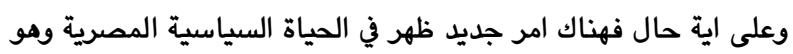
انتظام الاقباط في سلك الجيش في عهد الخديوي اسماعيل مع وجود نفور بين المسلمين والاقباط على السواء من الخدمة العسكرية في تلك
صدر المرسوم الخاص بتأسيس مجلس شورى في تشرين الثاني 1866 ينتخب أعضاؤه الخمسة والسبعون وكان معظمهم من الأعيان لمدة ثلاث سنوات وأكد الخديوي سعيد في كلمته أثناء افتتاح المجلس "إيجاد مجلس شورى النواب ليكون الأمر شورى بين الراعي والرعية") نص مرسوم عام 1866 ان كل شخص ييلغ عمره 25 عاما من حقه الترشيح للمجلس النيابي، بشرط أن يكون أمينا مخلصا وولد في مصر ومذه اشارة أشارة مهمة لمبدأ المساواة بين جميع المصريين،ونتيجة لمانية لذلك دخل المجلس جرجس برسوم عمدة بني سلامة عن بني سويف والفيوم،وميخائيل اثناسيوس عن اشروية من المنيا ويني مزار،وفي تشكيل المجلس عام 1870 دخل عضويته المعلم فرج إبراهيم عمدة ديرمواس عن أسيوط،وحنا يوسف عمدة نزلة الفلاحين عن المنيا ويني مزار(14) وقبل تشكيل المجلس تقرر ترشيح الأقباط في مجلس الشورى والدليل على ذلك فقد اجمع نواب المجلس بموافقتهم على قبول دخول أبناء

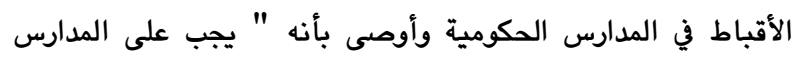

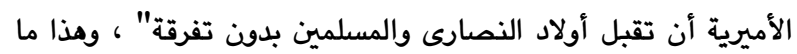

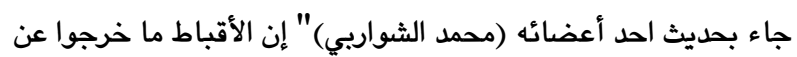
كونهم أبناء الوطن ، ولذلك يجب أن يكونوا ضمن المدارس التي تعمل

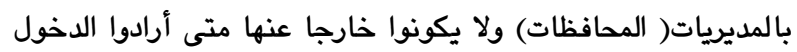
فيها"(15)ويذلك يكون مجلس شورى النواب انتخب عضوان من ولان يكان

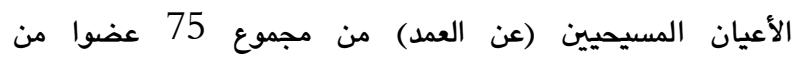
المجلس،لتكون بذلك بداية ظهورهم على الساحة السياسية في مصر

كانت مهمة برلمان 1866 المساعدة على مد السلطة السياسية على السكان الريفين وزيادة فعالية التجنيد والخدمة العسكرية وجباية الضرائب ويكون المجلس جزء من السلطة السياسية والتعليمية(17)كما كانت له سلطة محدودة وحق الانتخاب محصور في العمد والمشايخ

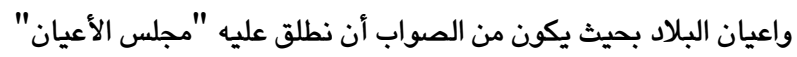
وكان الذديوي يريد فيه ان ينال تأييد المصريين وينوي إعلان الاستقلال عن الدولة العثمانية في حفل افتتاح قناة السويس(18) كما انه لم يكن له سلطات برلمانية مثل طرح الأسئلة والاستجواب وسحب الثقة من الحكومة ،ولم تكن له صلاحيات دستورية لانه لم تكن في مصر دستور بفصل بين السلطات ويحدد صلة كل منهما للأخر ،بل كانت مهمته تنفيذ المشاريع العامة في البلاد ، وتحديد مواعيد سنوية لجباية الضرائب والنفقات (19) وإذا كان مذا المجلس منحة كما وصفه المؤرخ المصري عبد الرحمن الرافعي(1966-1889م) من غير ان تسبقه حركة مطالبة من قبل

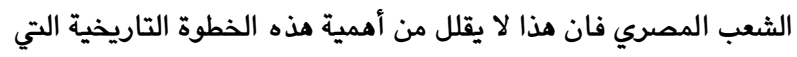
استمرت بالتصاعد لتشكيل الحركة النيابية ومؤسساتها الدستورية 
النواب وانتهاء مدته وعدم تحديد موعد للانتخابات الجديدة فاجتمع أعيان مصر ببيت الشيخ البكري ومعهم الأقباط(33). وقع الوطنيون اللائحة الوطنية الى إسماعيل باشا تضمنيا تضمنت قضايا عديدة منها تعديل النظام البرلماني وتخويل مجلس شورى النواب السلطات المعمول بها في البلدان الأوربية وان تكون الحكومة مسؤولة أمام الوزارة ،وكانت خطوة انتقالية جديدة على الساحة السياسية المصرية لتطور البلاد وقد وقعها العديد من الوطنيين المصريين من أعضاء مجلس النواب والتجار والأعيان ورجال الدين مثل الشيخ علي البكري نقيب الأشراف وحاخام اليهود وبطريرك الأقباط،الذين ألفوا وفدا وحملوما وإياه الى قصر عابدين ، وفي نفس اليوم 7 نيسان أمر الخديوي إسماعيل بإعفاء ابنه توفيق من رئاسة الحكومة وتكليف رشدي باشا بتشكيلها(34) قبل الخديوي اللائحة وأراد الظهور بمظهر الذي يعبر عن الآراء الوطنية والتخلص من الوزيرين الأوربيين فقدمت وزارة توفيق باشا استقالتها وكلف شريف باشا بتشكيلها وقد رحب بها الشعب المصري وتوجهوا الى قصر عابدين لتوجيه الشكر للخديوي ومنهم البابا كيرلس الخامس وأقام نقيب الإثراف مأدبة كبرى حضرما الخديوي والبابا نفسه تأكيدا للوحدة الوطنية التي أغاضت فرنسا وبريطانيا (35). وقد برز في هذا الصدد موقف بطرس غالي(36) بوجه الأطماع الأجنبية عندما كان وكيلا لرياض باشا في لجنة التصفية للدفاع عن مصالح الحكومة المصرية أثناء الضائقة المالية، ويأسه من تدخل بريطانيا

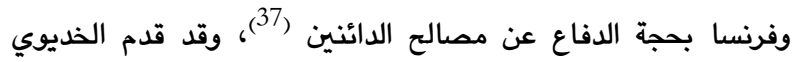
إسماعيل وصفا دقيقا عن الأقباط لنويار باشا في حديث له بخصوص انتخابات المجلس بقوله " عندنا أقباط أيضا بين المنتخبين وقد فتحنا

$$
\text { الباب للمسلمين والأقباط بدون تمييز"(38). }
$$

واكد رئيس الوزراء المصري اسماعيل باشا في نهاية سبعينيات القرن التاسع عشر،عبارة قالها للوالي التركي وذكرها المؤرخ شارم ايضا والذي كان شاهد عيان"يعيش المسيحيون في تركيا في جو من التسامح المشوب بالاحتقار واما في مصر يعيشون في جو من التسامح المقرون بالاحترام" (39). يلاحظ مما سبق ان عهد الخديوي اسماعيل يعد مدخلا لبويز نشاط سياسي قبطي على الساحة المصرية حتى وان كان ذلك مرفوقا ببعض الشعارات التي اراد الخديوي كسبها بسياستة تلك الا انه اراد بذلك بناء دولة متماسكة يستطيع من خلالها فرض سيطرته وحكم عائلته عليها ،ولذلك يلاحظ ان عملية تمثيل المصريين في المجلس كانت تشمل الاعيان والوجهاء في المجتمع ممن يضمن ولاءهم وارتباط مصالحهم بسلطته ، كذلك سعى من ذلك الى عزل مصر تدريجيا عن الارتباط

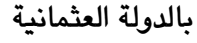

الفترة الا ان الطرفين ادركا انهما خاضعين لقانون التجنيد،وفي هذا الصدد يشير المؤرخ الفرنسي (القبطي الاصل)جبرائيل شارم Charmes امام القصر فقال الخديوي اسماعيل للكاتب"انظر الى هذه الكتيبة ان فيها عريا واقباطا،ومسلمين ونصارى،وهم يسيرون في صف واحد ،واني اؤكد لك انه لايوجد بينهم من يهتم بديانة جاره وان المساواة بينهم

تامة (26) وعند تنظيم شوارع القاهرة ومنها فتح شارع كلوت باشا كان لابد من مرود الشارع بالكنيسة المرقسية الكبرى ومقر البطريرك وهذا الامر يتطلب هدم الكنيسة ولما عرضت الحكومة على البابا ديمتريوس الثاني (1870-1862)ان تبنى كنيسة افخم منها ودار بطريركية افضل رفض البابا العرض وعرض على الخديوي مطلبه بالرفض الذي لم يتردد بحم القضية قائلا"لتكن ارادة البطريرك وليبقى المعبد(الكنيسة) قائما كما هو ويالفعل تغيرت خريطة تنظيم الشارع ويقيت الكنيسة على حالها الى يومنا هذا(27) . أما مجلس شورى عام 1870 فقد تضمن 75 عضو مصريا منهم يومنا هدئ من الاقباط فرج إبراهيم عمدة ديراموس من نواب أسيوط وحنا افندي يوسف عمدة نزلة الفلاحين من نواب المنيا ويني مزار، ومجلس 1876

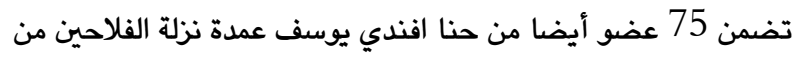

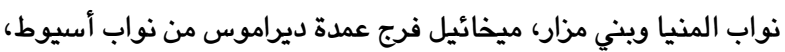

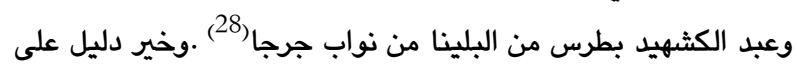
ذلك إجماع المجلس على وجوب قبول الأقباط في المدارس الأميرية أسوة بأقرانهم المسلمين، وشملت الأقباط بإرسالهم بالبعثات العلمية الى الخارج وابرذ من شملته البعثات جرجس قلدس القاضي وميخائيل كميل وفرج نصحي وغيرهم (29) في العام 1873م اتخذ الاقباط خطوة مهمة في سبيل توحيد صفوفهم عندما شكلوا المجلس الملي لنشر الالفة والتضامن بينهم، لإدارة شؤونهم الداخلية واتفقوا على انتخاب افراد الهيئة للمجلس في وقت لم يكن احد يستطيع الوقوف في وجه السلطتين

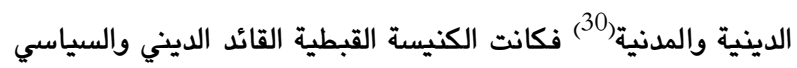
للاقباط في تلك الفترة والتي تقوم على فكرة أن المسيحية هي طريقة الحياة بكل قضاياها (31) في العام 1879 وقف النواب في البرلمان مع الخديوي في محنته المالية لذلك ورفضوا مبدا تسوية مشاكل مصر بإعلان إفلاسها وهو موقف وطني لا غبار عليه(32) ،لقد كانت المسالة المالية والرقابة الثنائية للوزيرين البريطاني والفرنسي وثورة الضباط المصريين ووزارة محمد توفيق ابن الخديوي إسماعيل سببا في تصاعد الأزمة السياسية في البلاد قام خلالها مجلس شورى النواب أثناء انعقاد الدورة الثالثة 1879 ويرئاسة احمد رشيد بإرسال عريضة للخديوي والاحتجاج المالي الذي يرفض إعلان إفلاس مصر إلا أن وزارة توفيق أوصت بحل مجلس 
ونتيجة لاستمرار تدهور الاوضاع السياسية والاقتصادية في مصر وزيادة تدخل بريطانيا وفرنسا في شؤون البلاد ولاسيما المالية منها في تلك الفترة نشطت الحركة الوطنية في مصر يساندها العسكريون الذين مثلوا غضبة وطنية على الاتراك والجراكسة ،مما ادى الى اندلاع الثورة التي قادها احمد عرابي (50). ادت هذه التغيرات الى احتضان البدو والقبط والاعيان فضلا عن عادي الفلاحين ، ولكن قيادتها كانت بيد الجيش فكانت ثورة عسكرية شعبية، وكان المصريون يومئذ يحاولون تحسين حالهم بحركة لها صفة وطنية ولايمكن تحقيق ذلك الا بتدخل الجيش في مثل هذه الاحوال(51).

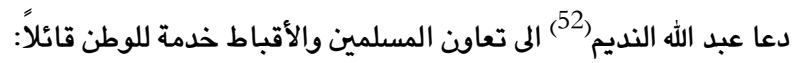
" إن اعز مكان بالنسبة إلينا هو مصر • وهو بلد مسلم ، يحيا فيه عدد غير قليل من الأقباط ، تربطهم الأواصر القومية بكثير ممن ولدوا لأناس اعتنقوا الإسلام في غابر الزمان ، والوطنية تحملهم بدافع حب الوطن

والانتماء الى مصر والحياة المشتركة فيها" وضمن مذا السياق اتسم الهجوم على الاحتلال في مجلة (الاستاذ) بطابع

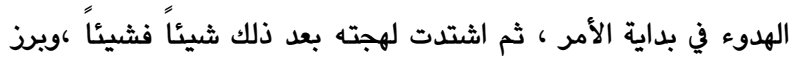
موقف عبد الله النديم في مواجهة صحف الاحتلال ، استطاع عبد الله النديم عن طريق المجلة ان يوقد الجذوة الوطنية المصرية ،وحماسة الشباب المصري ، الأمر الذي حمل سلطات الاحتلال على تعطيل المجلة(53). ويذكر شاهد عيان كان في مصر ابان الثورة العرابية بقوله " تقريبا كل طبقات المجتمع المصري الذين يتحدثون عنا يكرهوننا ويودون التخلص منا ...ان كثيرا من جماعات المصريين الذين كانوا يشتغلون اثغالا ثاقة وهم ساكتون لايتجاسرون على تقديم الشكر للانكليز سواء كانوا مسلمين او اقباطا....لغيرتهم الوطنية" (54). واسهم الاقباط في الثورة الوطنية عندما انهالت التبرعات على عرابي منهم ولاسيما من اقباط الصعيد الذين كانوا يتمنون من كل قلبهم التخلص من سلطة الخديوي والسلطان(55)، وقام عرابي بالمطالبة بتشكيل مجلس الأمة ووافق الخديوي على ذلك وافتتح المجلس في كانون الثاني 1881 إلا أن فرنسا ويريطانيا اعترضتا على ذلك بمذكرة احتجاج (56). (5انون وفي خضم هذه التطورات عقد الوطنيون مؤتمرا لكبار رجال الدولة و

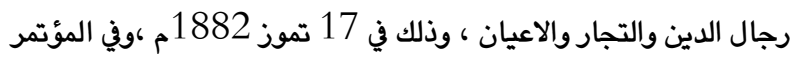
اخذ برأي البابا الذي اقترح تشكيل لجنة لمعرفة موقف الذديوي المتواجد في الإسكندرية وتبنى غالبية المؤتمر رايه مع الاستمرار بالتجهيزات الحربية وقرد الاجتماع التنديد بموقف الخديوي ومن ثم عزله في 29 تموز وتكليف عرابي بالدفاع عن البلد (57).
عهد الخديوي توفيق: ورث الخديوي توفيق(40) دولة مفلسة واقتصادها تحت الرقابة الثنائية منذ عام 1879 ويتحكم بها طبقة من الأتراك والجراكسة، وظهرت في ايامه الاتجاهات الفكرية الاصلاحية واهمها المتمثلة بجمال الدين الأفغاني(41) الذي دعا الى إقامة خلافة إسلامية وتنقيتها، كذلك محمد الاهد

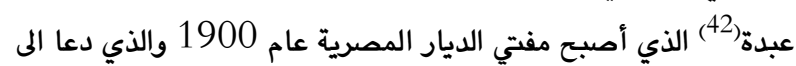
إصلاح المجتمع ، يضاف الى ذلك تأثير الإرساليات الدينية المسيحية الكاثوليكية والبروتستانتية التي كانت منتشرة في المنطقة العربية

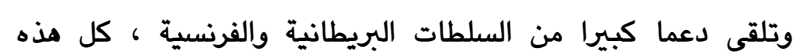
المتغيرات عملت على صقل افكار الشعب المصري بمسلميه واقباطه.

ولذلك عندما حاول الخديوي توفيق، تحت ضغط سلطات الاحتلال

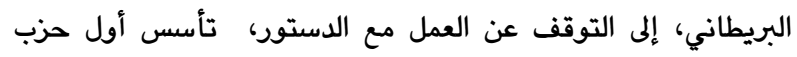

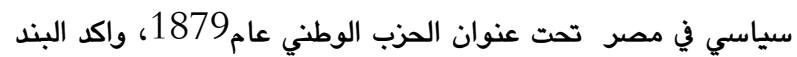
الخامس من فصله أنه "حزب سياسي لا حزب ديني"، وانضم اليه

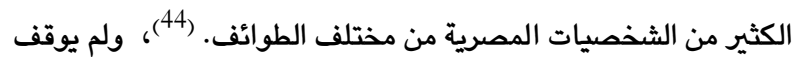
ذلك الخديوي توفيق وحكومة رياض باشا عن حكم البلاد حكما مطلقا فتعطل مجلس شورى النواب وتجمد العمل بدستور 1879 الذي أعدته وزارة شريف باشا، ويدأت بوادر ثورة مصرية كانت الحجر الأساس

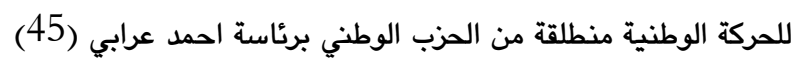
والذي وضع برنامجه محمد عبدة ولويس صابونجي والذي أكد في مادته الخامسة كما على وحدة الشعب المصري الواحد بصرف النظر عن المعتقد ، ولذلك جمع بين صفوفه مختلف طبقات الشعب المصري (46)

كان عرابي ابرذ مؤسسي الحزب وترأسه محمد شريف باشا واتخذ من حلوان مقرا له. وجرى اتصال بين الجمعية السرية لضباط الجيش المصري (مصر الفتاة) و (الحزب الوطني الاهلي) لتوحيد العمل بينهما ، فتم الاندماج وأعلن عن قيام الحزب الوطني الذي انيطت قيادته بعرابي وضم نقيب الأشراف السيد البكري ، والشيخ الخلفاوي ، واسماعيل راغب باشا (كان رئيسا لمجلس شورى النواب ووزيرا سابقا) ، وسليمان اباظة باشا (محافظ الشرقية) ، وحسن الشريعي (محافظ

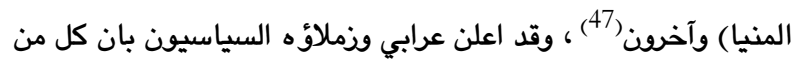
الزعامة القومية والشعب المصري هم شعب واحد بغض النظر عن ون ديانتهم (48). ونشرت جريدة التايمز اللندنية عام 1982بان الحزب الوطني اعلن برنامجه الذي تضمن " اقامة حياة نيابية والفصل بين السلطات التنفيذبة والتشريعية ..وإطلاق الحريات. .كما واعلن بانه حزب سياسي لا علاقة له بالأديان فالجميع اخوة والكل متساون في الحقوق

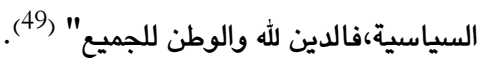


أما فيما يخص موقف الخديوي ومجلس النواب في فترة الاحتلال فقد ذكر اللورد لويد بانه كان يحكم دستوريا صوريا، وكان مجلس الوزراء عبارة عن مستشارين له، ومصر جزء من الممتلكات العثمانية والخديوي كان يشغل منصبه بمرسوم صادر من السلطان العثماني الذي كانت سيادته معترف بها في مصر (66). اتجه الاقباط عندما ثم اقصاؤهم الى الإعلام مرة أخرى لإثبات حقوقهم فلجأوا الى جريدة الوطن التي أنشاها ميخائيل السيد أواخر عهد إسماعيل ،وجريدة مصر لمؤسسها تادرس بك شنودة المنقبادي عام 1895،وانشأوا المتحف القبطي ،وكانت سبب نكبة الأقباط في هذه الفترة أيضا ضعف القادة وعدم وجود الاكليروس القوي الذي يرعى شعبه (67). ويظهر لنا أول اتجاه فعلي نحو محاولة فصل الدين عن السياسة عند الأقباط مو المطالبة بإصلاح الكنيسة القبطية والتي تعد أعلى سلطة دينية ينتمون إليها وقد تجلى ذلك واضحا في نهاية القرن التاسع عشر وتحديدا في عام 1890 عندما أسس بعض صغار الأقباط جمعية التوفيق الخيرية القبطية لإصلاح الكنيسة القبطية سميت بجمعية التوفيق القبطية الخيرية وهدفها نشر نبذات ومختصرات باللغة العربية الغرض منها استنهاض الرأي العام بين جميع الأقباط الذين يعرفون القراءة والكتابة وقد ترجم بعض هذه النشرات الى اللغة الانكليزية فكبرت الجمعية وأصبح لها مؤيدين كثيرين ، وتحولت الى أول نشاط سياسي على ارض الواقع سجل لهم يعود الى عام 1891 عندما قاموا بمظاهرة حضرها جميع الأقباط من كافة المحافظات المصرية لإصلاح حالهم والالتفات الى صوت الشعب( وقبل ذلك كان البابا كيرلس الخامس (1874 - 1927) قد ورث رئاسة المجلس الملى رغماً عنه ووجد معه تقليصاً لسلطانه فسعى إلى حله وتجميد دوره . ويذل بطرس غالي جهدا لتفعيله لما رأه من سوء

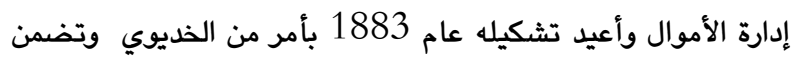
حصر الأوقاف والمدارس والأديرة وجمع حججها ومستنداتها وادارة المدارس والمطبعة ومساعدة الفقراء، الفصل فى منازعات الزواج والطلاق وغيرها .يكون رئاسة المجلس في حالة غياب البابا لأحد أعضائه،يتشكل من 12 عضواً و 12 نائباً يضافون إلى الأعضاء

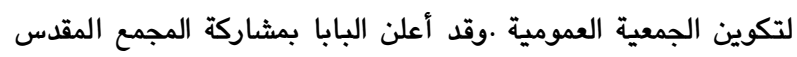
عدم تقيده بتلك اللائحة (69). صار المجلس فى حكم المنحل حتى عام 1891 حين طالب الأقباط

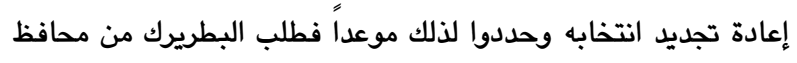
القاهرة منعه فتدخل بطرس غالى لحل المشكلة .عندها كتب البابا إلى الحكومة معلنا أن المجلس الملى مخالف للدين المسيحي،مما اضطر الى الاتفاق بين الطرفين على حل وسط يقضى بالتنازل عن كثير من

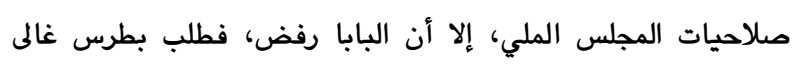
وأعيان الأقباط من الحكومة نفى البابا ومساعده الأنبا يؤانس مطران

\section{3. الأقباط و الاحتلال البريطاني الاول1882-1914}

نشأت الثورة العرابية تحت شعار "مصر للمصريين "، وخلال تلك الفترة شعرت بريطانيا رغم قوتها بالتهديد ألا وهو قيام ثورة وطنية ضدها،وقد لجأت إلى أساليب مختلفة منها محاولة زدع الفتنة بين المصريين لاسيما بين المسلمين والاقباط والتعامل مع الأقباط على أساس عرقي لعزلهم عن الحركة الوطنية التي تحاريها لتفتيت المؤسسات الدينية القبطية المحلية، وتزامنت هذه الآلية مع مصالح الدول الأخرى تحت ذرائع دينية منها حماية فرنسا للكاثوليك، وحماية روسيا للارثوذكس والولايات المتحدة الأمريكية للترويج للكنيسة

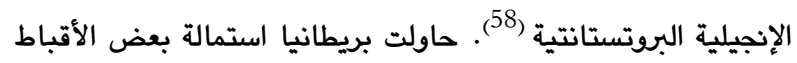

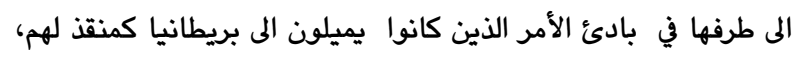
مستغلين قول عرابي" إن وجود الأقباط في السلطة عرض الإسلام الى لى المخاطر"، الا ان هذا الامر لم يستمر طويلا بعد ان تبين ان بريطانيا

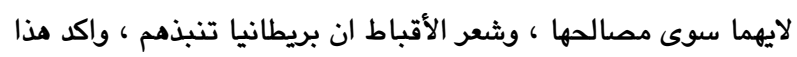
التوجه قول اللورد كرومر بان "مبادئ الحياد التام التي سارت عليها بريطانيا كانت غريبة على الأقباط(59)، والدليل على ذلك بانه لموله لم يمض ريع قرن على الاحتلال البريطاني لمصر حتى اختفى أكثر الرؤساء القبط من الإدارات والمناصب العليا في البلاد وقل عددهم بالتدريج

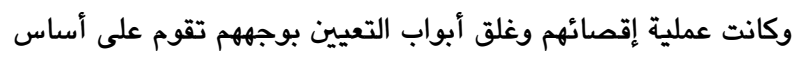
إحلال السوريين محلهم بحجة أن طريقة حسابهم قديمة وغير مفهومة،ولا يفوتونا أن نذكر بان هذا الإقصاء شمل المسلمين أيضا بحجة أن لا فائدة منهم في تلك المرحلة من تاريخ مصر (60). ان سياسة بريطانيا ابعاد الاقباط عن مراكز التأثي في مصر على الرغم من كونهم مسيحيين ، يأتي ضمن سياق " منطقية الشرق " و " "

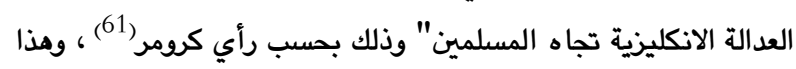
الامر يؤكد النهج البريطاني بعدم ثقتها باي طرف من الوطنيين

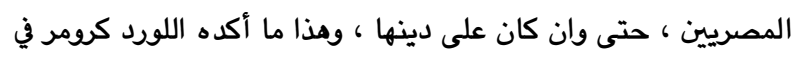
حديث له بأن: " الفرق الوحيد بين القبطي والمسلم هو أن الأول مصري يعبد الله في كنيسة مسيحية، في حين أن الثاني مصري يعبد الله في مسجد مسلم " (62). ويذهب رأي اخرالى ان الأقباط لم يظهروا يثقوا تجاه ما اسماهم" المصلحين الانكليز" يقصد الاحتلال البريطاني ، وان الانكليز ادركوا ليطهاي

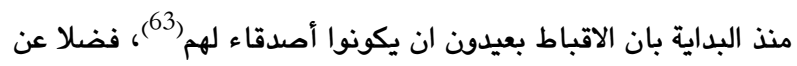
ان غاية بريطانيا كانت تهدف الم دعم الأغلبية على حساب الأقلية ، فعمدوا الى إبعاد كل المسيحيين من الوظائف العليا مثل مديري المديريات( المحافظين) ورؤساء المحاكم، ونظارة المدارس ومنتسبي الداخلية والمالية والقضائية بحجة أن هذه الوظائف تعود لحاكم البلاد المسلم(64).غير ان مذا الامر فشل ايضا مع المسلمين في اثارتهم ضد الاقباط ، لذلك لم يتردد بلنت في التاكيد على ان العلاقات بين المسلمين

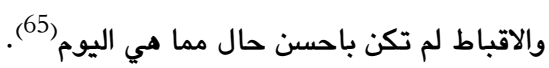


والحضاري والاجتماعي والثقافي والنفسي لتبلور المفهوم القومي للجماعة السياسية المصرية(77). لتبدأ أواصر القومية المصرية تظهي والفير على الساحة السياسية المصرية لأكثر من عقد من الزمان (78). وهذا النهج الوطني في مواجهة التطورات السياسية بدا واضحا حتى بعد مدئ بروز مصطفى كامل(797)، الذي يعد من ابرز الوطنيين المصريين والذين لعبوا دورا كبيرا في الحركة الوطنية وكان يطلق عليه" باعث الحركة

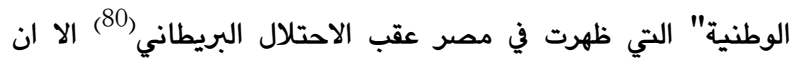
الاقباط نظروا اليه كمصلح تحت لواء الدولة العثمانية، لانه طالب

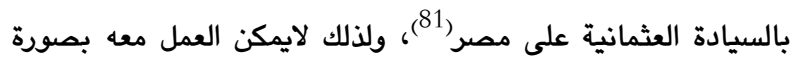
مطلقة ودون تحفظات . كما نرى انهم لم يقفوا اللى جانبه فبالرغم من كونه رجلا وطنيا يطالب بخرج المحتل من مصر وذلك لاسباب منها انه لم يمس الأتراك في خطاباته الوطنية وامن بالولاء التام للسلطان عبد الحميد الثاني(1870م - 1908م) وامن بالجامعة الإسلامية دينيا وسياسيا، لذلك رفض الاقباط تبديل " السيد البريطاني بالسيد العثماني" على حد تعبيرهم، ولم يستطيعوا ان يؤمنوا بمصطفى كامل وهم يرون رجال الحركة الوطنية في تركيا يهربون الى اوريا من طغيان السلطة العثمانية بينما كان مصطفى كامل يسافر سنويا الى استانبول ليلقى كل الاحترام والترحيب ، فضلا عن انه منحه لقب الباشا،ولم يستطيعوا ان يقبلوا فكرة ان يضع التركي والافغاني وغيرهم الى جانب المصري المسلم على قدم المساواة ثم تضع القبطي المصري في مرتبة اقل منهم فالقومية المصرية كما يفهمها الاقباط هي ان خيرات مصر حلال للمصريين وان اختلفت ديانتهم وحرام على غيرهم (82) . وزاد من نفور الاقباط من مصطفى كامل اندفاعه في تاييد السلطان عبد الحميد الثاني في اعماله الاستبدادية فوصم الوطنيون الاتراك الذين

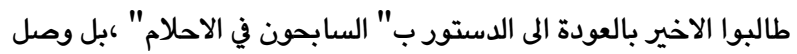
الامر به الى تهديد المصريين من اعضاء حزب الامة الذين طالبوا بان تكون مصر للمصريين بتقديمهم الى المحاكمات لان السيادة العثمانية مقررة فيه(83)، رغم ان الحزب الوطني لم يكن في الحقيقة يؤيد السيطرة التركية الا ليستخدم نفوذها للوقوف بوجه الاحتلال البريطاني( (84). الا انه وكما اشرنا سابقا بان المناخ الحضاري والاجتماعي الذي اصبح راسخا في فكر مسلمي مصر وقبطها وادى الى بروذ شعارات مصر للمصريين ، ادت الى تغيير موقف مصطفى كامل،الذي اعلن عام 1896م "ان الراية العثمانية هي الراية التي يجب ان يلتف حولها موقفي المصريون وان استقلال مصر عن الدولة العثمانية ضار ببقاء تلك لك الدولة" ليعود عام 1907 ليقول "نحن لانود الا ان نكون قوة محالفة للدولة العلية"(85) ، وقد حاول مصطفى كامل ان يلحن من قوله في مقال له بان السيادة الحقيقية على مصر هي سيادة تركيا " الشعار الذهبي لتلك المرحلة عدو عدوي صديقي، وأكد كامل ذلك بقوله " انصر أخاك
البحيرة، فصدر أمر خديوي بنفي الأول بدير البرامواس و الثاني بدير الأنبابولا بالبحر الأحمر وتم تعين الأنبا باسليوس نائباً للبطريركية(70) أثار ذلك غضب الأقباط وخاصة رجال الدين وألبوا الشعب على الحكومة وقرارها وسعى الأساقفة لدى قنصل روسيا والذى نشط لدى الباب العالى مما دفع رئيس الوزراء رياض باشا لإصدار قرار عام

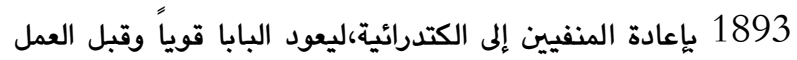

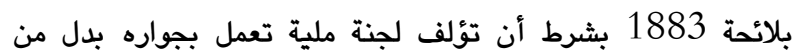

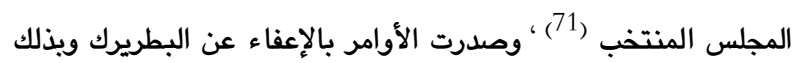
لم تنجع بريطانيا بمساعيها بجعل الكنيسة القبطية الأرثوذكسية بروتستانتية المذهب ويكون جميع الاقباط تحت حماية بريطانيا (72). اما في مايتعلق بعلاقاتهم مع الحكومة المصرية والخديوي الرسمية فانه وعلى الرغم من أن الاحتلال البريطاني قد أزاح الكثير من الأقباط عن مناصبهم ووظائفهم ، فان الأخيرين ظلوا يحتفظون ببعض المناصب، وهذا يتضح لنا من خلال تولي الكثير منهم الحكم على مناطق مختلفة من البلاد، فمثلاً عين بطرس أغا ارمانيوس حاكماً على وادي برديس الذي يشمل القسم الشمالي من مديرية قنا والجنوبي من جرجا، وعين عيد فرح أغا ميخائيل حاكماً على بعض مراكز أسيوط مثل دير مواس،

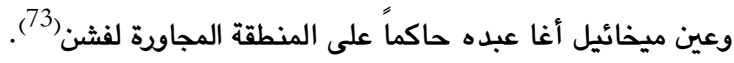
ورغم الجهود التي بذلها كرومر في محاولة التفريق بين المسلمين والأقباط وإثارة الفتنة بينهما كخط ستراتيجي استعماري فانه اعترف بهن بالامتزاج الكامل بين عنصري الأمة اذ يقول بان تجريته الخاصة تقوده الى عدة نتائج،منها ان القبطي اكتسب خصائص اخلاقية يتصف بها المسلم المصري،وان هذا الاكتساب يرجع الى ظروف ليس لها علاقة بالاختلاف في العقائد،بسب حنقه الشديد على الاقباط وعدم استجابتهم للمشاريع الاستعمارية البريطانية وقد ماجمهم هجوما شديدا الى حد إنكاره لمسيحيتهم إذ قال " ان القبطي رغم عقيدته اصبح معتقلا في ذات الأغلال التي قيدت المسلم وان القبطي من الرأس المى

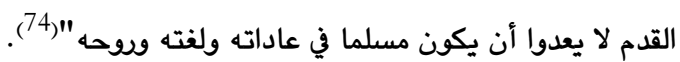
ومع مطلع القرن العشرين بدأت الأفكار تتجه نحو الوحدة الوطنية وازداد استخدام شعارات مصر للمصريين ويدأت الحركة الوطنية بهودما التي أخذت تتجه نحو الوحدة الوطنية

إن المثقفين المسيحيون وتبعهم المسلمون وكلهم علمانيون رفعوا

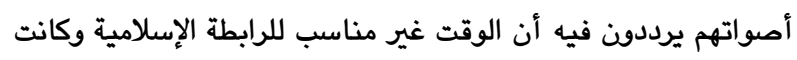
الشعارات مناسبة لظروفها وكانت لا تعوزها التبريرات لان العثمانيين المسلمون بالأمس لم يستطيعوا وقف الزحف الأوربي على الأراضي العربية (76).

كان الإسلام ومسيحية القبط من ناحية والامتزاج الحضاري بين المسلمين والأقباط في مصر من ناحية أخرى قد كون المناخ التاريخي 
والدستور ضد الأقباط،وإعادة الطمأنينة الى أوربا بإفهامها أن الحكومة

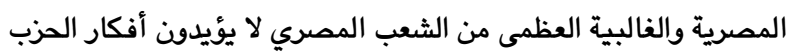

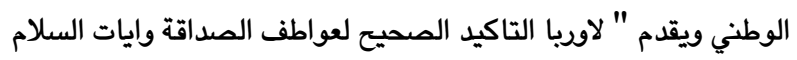
التي ترغب بها مصر."(92) - (92) وعندما اضطربت الامور بين العرابيين والخديوي طلب بطرس غالي من عرابي باشا التريث وان يطلبوا الصفح من الخديوي كي لايتخذ اعداء البلاد هذه الفرصة للدس بين أبناء الوطن الواحد فانصاعوا

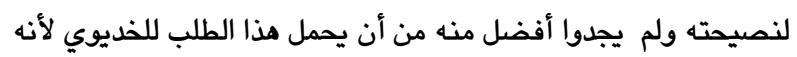

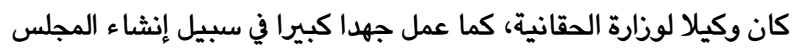
الملي فقد عرف كيف يجعل الحكومة على ان تجافي الرئاسة الدينية على ما بيدها من أموال للتصرف فيها بما فيها خدمة للشعب ويهذه الخطوة

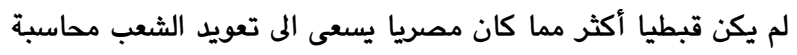

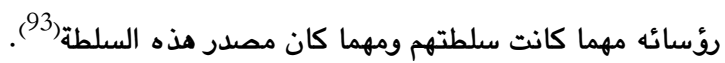
وعندما حاول اليهود إنشاء وطن قومي لهم في مصر بعد إرسالهم بعثة

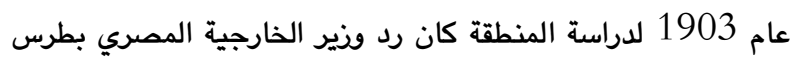
غالي "لا تستطيع وفق القرارات الشاهانية لاي سبب او مبرد التنازل عن جزء أو كل الحقوق المتعلقة بالسيادة وكذا فانه يجب أن نستبعد

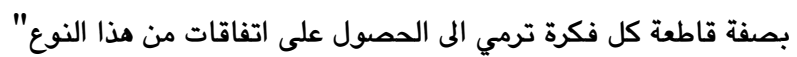
وفي نفس اليوم ارسل اللورد كرومر الى حكومته صورة من رد الوزير النقال

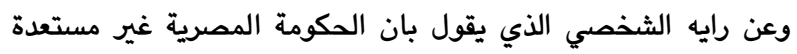

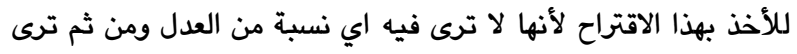
وجوب صرف النظر عن هذا الموضوع (94).

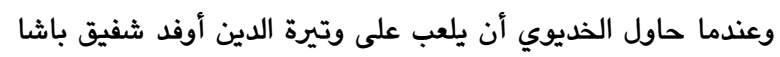

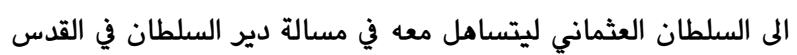
الذي كانت الكنيسة المصرية تتمسك بملكيته والموافقة على وجهة نظرها لقاء رضا بطرس باشا القبطي فيتساهل في تبعية سيناء لمصر

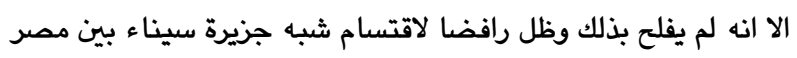

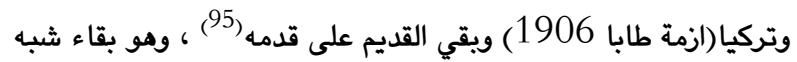

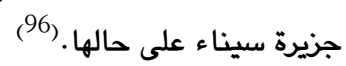
فضلا عن ذلك فان بطرس غالي هو رئيس الوزراء الأول الذي قرر علنية جلسات مجلس الشورى بعد ان كانت سرية وجعل الوزارة مسؤولة أمام المجلس عن أعمالها ومكن السلطة الدستورية المصرية ان تصبح سلطة

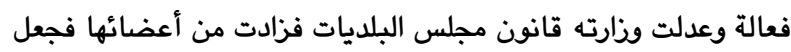
لكل مركز عضوين وخولت هذه المجالس سلطة فرض ضرائب إضافية

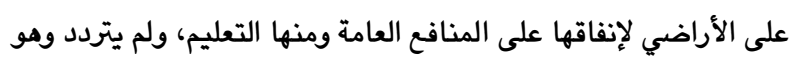

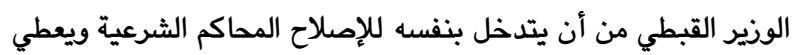

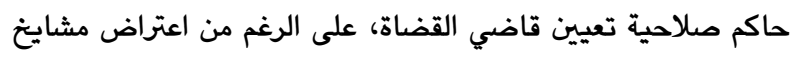

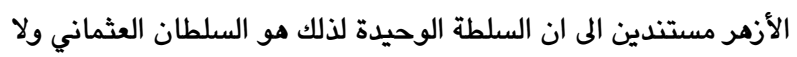
يحق للحكومة المصرية بإحداث اي تغيير في الهيئة الشرعية لان ذلك الك الكان الكان
ظالما أو مظلوما" ، إلا واقع الحال أن الشعب المصري كان يرفض الاحتلالين البريطاني والعثماني (86). حاول الحزب الوطني ان يضم في صفوفه عددا من الأقباط في عهد كامل

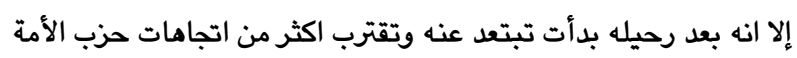
الذي كان يعمل في أناة لبناء الوطنية المصرية والقومية المصرية ووجد في صفوفه عددا من الأقباط (87)

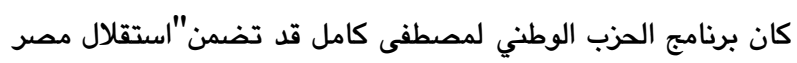

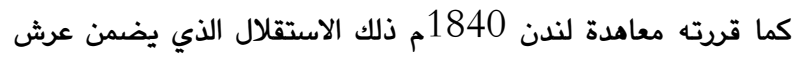

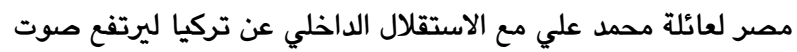
احمد لطفي السيد ليكتب في صحيفة الجريدة وينادي مصر للمصريين

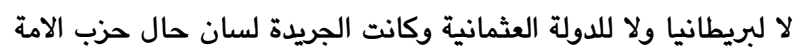

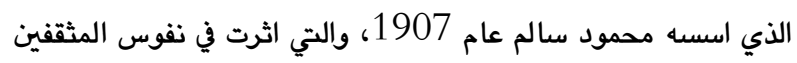
وقامت دعوته على ضرورة توجيه الامة نحو الوعي السياسي والقومي في مصر وجهة مصرية خالصة لا ارتباط بينها وبين دولة الخلافة (88). اتسعت مشاركة المسيحيين عموما في الحياة السياسية المصرية ودخلوا الأحزاب التي بدأت بالتأسيس منذ العقد الأول من القرن العشرين فاشترك اثنان منهم في تأسيس حزب الإصلاح على المبادئ الدستورية والذي تزعمه الشيخ علي يوسف ، كما انضم مرقس حنا و ويصا

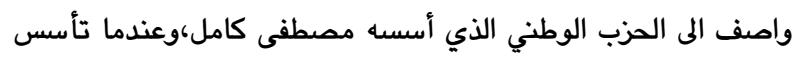

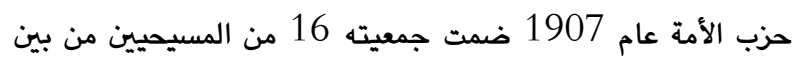

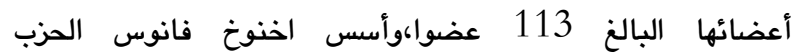

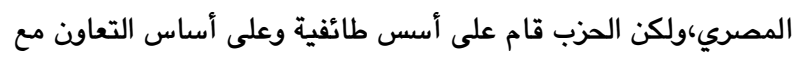

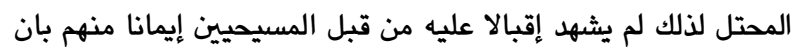

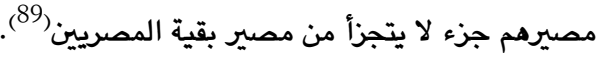
راى الأقباط في حزب الأمة ما يعارض الاتجاه الديني فانضم اليه 14 قبطيا أصبح احدهم ضمن اللجنة الادارية، وتضمن برنامج الحزب لإناهي

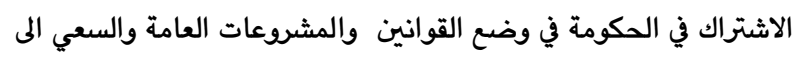
توسيع صلاحيات مجالس المديريات ومجلس شورى القوانين والجمعية العمومية والنهوض بالتعليم (90) وهنا شرعت سلطات الاحتلال البريطاني في تنفيذ سياستها لأحداث شقاق بين المصريين، وكان في مقدمتها توظيف الاختلاف في العقيدة الدينية بين مسلمي مصروأقباطها، لكبح الحركة الوطنية وإثارة الفوارق الدينية وحق الأغلبية في تولي المناصب السيادية، ونجحت في استمالة

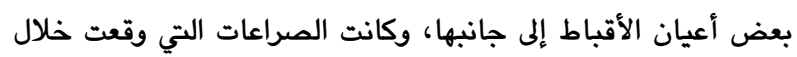

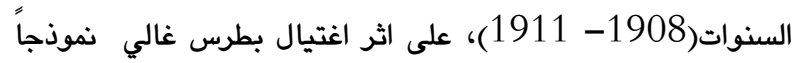
للصراعات الطائفية التي أدارتها سلطة أجنبية، والتي أدت إلى الاحتقان الدموي(91) كان بطرس غالي اول مواطن مصري يتولى الوزارة لأنه كان على حد

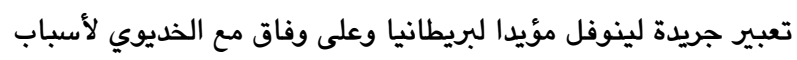
وجدما الأخير مهمة منها الحملة التعصبية التي قامت بها صحف اللواء 
ويدأت الافكار القومية المصرية والدعوة الى المساواة والتي قادها

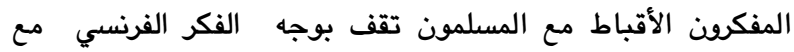
الليبرالية البريطانية، كذلك رفض الأقباط التعاون مع بريطانيا ورفعوا شعار مصر للمصريين (106) والتطور الذي حدث المتمثل بالمؤتمر القبطي والذي دفع بمطالب تؤكد مدنية الدولة ومبدا المواطنة من خلال مطالبهم الخمسة فعلى بالرغم من عدالة هذه المطالب وشرعيتها الا انها جاءت في غير ظروفها،فالصراع في مصر كان غربيا اسلاميا ومازال ارتباط مصر بالدولة العثمانية قائما ، ومع ذلك فقد اخذت المسالة تناقش على اساس مدني وليس على اساس ديني (107). بدا بطرس غالي اتصالاته عن طريق المؤتمرات والمحادثات لبحث مسالة جلاء بريطانيا عن مصر، ممثلا مصر وليس ممثلا عن الاقباط في وقت تغلبت فيه النعرات الدينية.(108)

\section{4. - دوافع الاغتيال وتداعياته :}

كان حادث اغتيال يعود لأسباب عديدة تقف في مقدمتها حكمه على الفلاحين في حادثة دنشواي 1906 بالإعدام على الرغم من أنهم ضحايا الاعتداء البريطاني،فضلا عن توقعيه اتفاقية مد قناة السويس لمدة أربعون سنة مقابل أربعة ملايين جنيه، نيابة عن الحكومة المصرية

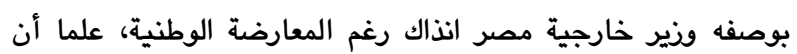
اتفاقية المد بقيت في طي الكتمان لمدة عام لولا تسرب المعلومات وهياج الشعب ومطالبته بعرضه على الجمعية العمومية والتي رفضته كذلك توقيعه اتفاقية السودان 1899رغم معارضة الشعب، واعاد العمل بقانون المطبوعات عام 1906 والذي يخول لوزير الداخلية حق انذار الصحف وتعطيلها دون محاكمة ، ويالمقابل فقد عملت سياسة فرق

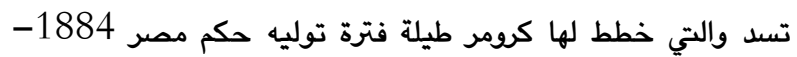
1907، لشق الصف الوطني وفصل الأقباط عن المسلمين وتفتيت

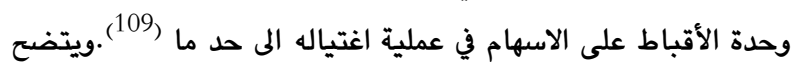
ذلك من الإثـاعات التي بثتها الادارة البريطانية في مصر وحاولت تصوير حادثة الاغتيال على أنها تمت لأسباب دينية ،فأشاعوا الهتاف الاتي:

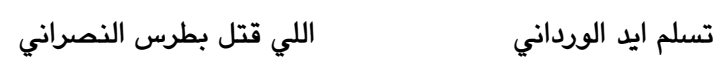

فاسرع الحزب الوطني بزعامة محمد فريد (1919-1868) بحشد الورداني الوطنيين الذين راحوا يصححون الهتاف المغرض بهتافهم: تسلم ايد الورداني اللي قتل بطرس البريطاني (110) واورد الودراني اسباب الاغتيال بانه بسبب توقيع اتفاقية الثنائية بين مصر والسودان عام1899،واعادة العمل بقانون المطبوعات القديم في 1909 وقانون النفي الاداري في نفس العام،ورئاسته لمحكمة دنشواي عام 1906 باعتباره وزيرا للحقانية(العدل) انذاك، وتوقيعه

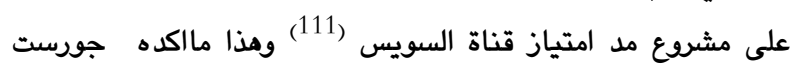

ليس من اختصاصها، وهو بذلك يؤكد قوله الذي عرف عنه قبل وفاته

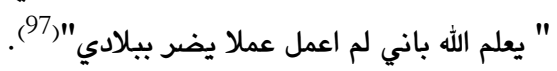
وعندما حدثت الخلافات بين الحكومة المصرية وثيوخ الأزهر بادر بار بمري بطرس غالي الى حل الخلاف بينهما بصفته رئيس الوزراء الذي وصل الأمر الى مخالفة اوامر الخديوي ووردت اليه أخبار غلق الجامع الأزهر

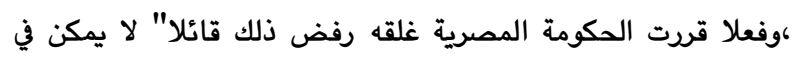
عهدي أبدا أن يمس الأزهريون بسوء وكانت تلك باكورة أعماله (98). وقد كانت جريدة الوقائع المصرية قد نشرت في ملحق لها في كانون الثاني 1909 " بمناسبة السنة الهجرية الجديدة ستقفل نظارت الحكومة ومصالحها يوم السبت أول محرم، سنة 1327 - 23 يناير 1909" ومكذا تقررت العطلة في أهم مناسبة إسلامية في عهد رئيس ونراء قبطي (99). وتذكر بعض المصادر بانه عندما تولى بطرس غالي الوزارة بدات التوجه عند الاقباط نحو اقامة حكم ذاتي لهم في مصر ويؤكد المؤرخ القبطي تادرسي ذلك ايضا بقوله" بانه بدا يظهر لدى الاقباط الميل

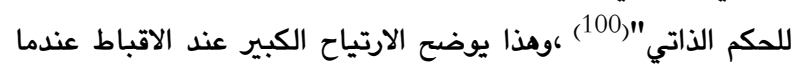
تولى غالي الوزارة لتحقيق مطالبهم بالمساواة، ولكن حنكته وحرصه الهي الدياح على ابناء الاقباط جعله يرد عليهم قائلا" اني لا انوي التدخل في هذه بهاه المسالة فابعدوا عنكم كل هذه الامال الان" (101).

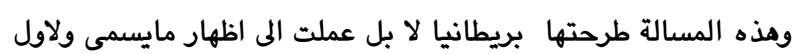
مرة "مساله حماية الاقليات " وقد عرضت بريطانيا هذه المسالة على لى ولى البابا الذي رفض ذلك فقال قوله الشهير "ان المصريين شعب واحد والذي يحميهم هو الله"وكان سابقا قد رفض عرض كرومر بمنح

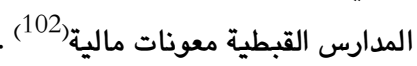
من جانب اخر فقد لعبت الجماعات الاملية القبطية دورا هاما في اذكاء روح الوحدة الوطنية ضد الاستعمار البريطاني ويرصد تقرير الحالة الدينية في مصر التعاون بين الجمعيات الاهلية والاسلامية والقبطية في التيدية بدايتهما " ان المراحل الاولى لنشاة الجمعيات المسيحية وخاصة القبطية الارثوذكسية لم تشهد صراعا بينها وبين مثيلاتها الاسلامية بل بل بله على النقيض شهدت تعاونا بين الفريقين في مواجهة نشاط الارساليات الاجنبية والاحتلال البريطاني (103) ولم تؤد الفتنة التي زرعها الاحتلال البريطاني الى ترسيخ النزعة البريطاني الانفصالية تلك ولم تكرس قيام طائفة قبطية ترتبط ارتباط ولاء ومصلحة بالقوى الخارجية لان اليات التكامل والاندماج هي التي كانت ترجح في نهاية المطاف ،لابل انه نلاحظ بعد الفتنة عام 1911 اخذت لتان الحركة الوطنية تجمع قواها لتخوض معركة جديدة من اجل الاستقلال الوحدة (104)، وكان جل ما يطمحون إليه مو الحرية والاستقلال والمساواة بين كافة المواطنين المصريين بعيدا عن الدين اول الطائفة (105). 
المواطنين المصريين في كل الحقوق والواجبات وفي الوقت نفسه عقد المسلمون مؤتمرا إسلاميا في مدينة الإسكندرية لمناقشة امر مؤتمر اسيوط مذا،وقد انزعج الخديوي من المؤتمرين على حد سواء (119).

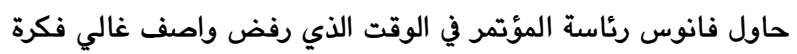
انعقاده وتدخلت شخصيات معتدلة لادارته وقد واصبح بشري حنا وسينوت حنا المسؤولين عن المؤتمر منعا لاحداث فتنة كبيرة تؤدي الى الشقاق في صفوف الوحدة الوطنية وعندما عارض الحاكم البريطاني جورست انعقاد المؤتمر تدخل المسلمون وذكروا بانه من حق الاقباط عقد مكذا مؤتمر (120). كان منظموا المؤتمر يتكونون من 12 الف قبطي من مجموع 700 الف قبطي،ومن طبقة صغيرة من الاثرياء الا ان البابا كيرلس الخامس رفض اجراءهم هذا(121)وابدى تخوفه من انعقاد المؤتمر واصدر بيانا ذكر بانه كان يسره ان اجتماع كلمة ابنائه على مافيه الخير للجميع وليس بدعوة الجمع الغفير كما ذكر شاهد عيان حضر المؤتمر قائلا بانه اعجبه ماسجله المؤتمرون من التاكيد على الانتماء للوحدة الوطنية فارتفع العلم المصري فوق مكان الاجتماع ويدا يعزف السلام الخديوي ، ومن جهته دعا الى نفس المبادئ في المؤتمر الذي عقده المسلمون المؤتمر المصري والذي تولى رئاستة رياض باشا المعروف بعدائه للثورة العرابية الا انه هنا حاول تهدئه الموقف ، وقد اتهم الأقباط بلدي بجماعة يهوذا وهاجموا البابا كيرلس الخامس وتحدث ابراهيم الغزالي في المؤتمر المصري قائلا" لقد تنبه لتلك المضار اغلب مواطنينا الاقباط مقدرين الوحدة الوطنية حق قدرها(122)وكانت فكرة انعقاد المؤتمر منذ ان كان بطرس رئيسا للوزراء الا انه وقف ضدها لياتي مقتله محرضا لانعقاده(123) عرض الأقباط مطالبهم على الحكومة المصرية وإلى اللورد كرومر والتي تضمنت إغلاق المدارس ودوائر الدولة أيام الآحد، وإلى ضبط النفس على اثر حادثة الاغتيال، وتعيين الأقباط في المناصب السيادية في الدولة، وتخصيص مبالغ من الحكومة للمدارس القبطية وغيرها ووجهت دعوات لحضور الأعيان الأقباط والأعيان والمثقفين المسلمين للمؤتمر في مليوبوليس، وقد استجابوا لذلك وتمكنوا في المؤتمر من إنهاء تلك الأزمة(124)،والتي انتهت باستجابة الحكومة المصرية ايضاً لبعض إنهاء مطاليب الأقباط منها ، تثبيت تدريس مادة التربية المسيحية في المدارس الأميرية لأبنائهم المتواجدين في تلك المدارس، وتعيين أعضاء أقباط في رابطة المحاميين (Bar Association)، وجعل يوم الأحد عطلة رسمية لجميع المسيحيين، ويذلك تم احتواء جزء من أزمة الاحتقان الدموي التي وقعت بين الطرفين ويتحريض من سلطات

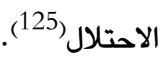
دعا لطفي السيد الى الاحتفال بعيد الهجرة النبوية في كانون الثاني

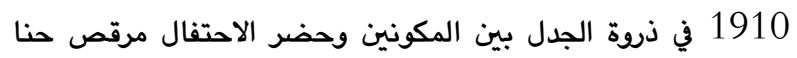

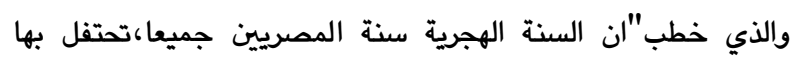

Gorst ان الباعث للقتل هو سياسي ايضا (112). جاءت حادثة الاغتيال بعد أن كانت الحركة الوطنية قد قطعت شوطا كبيرا واثتد ساعدها بمطالبتها وشعاراتها المعادية للاحتلال البريطاني لاسيما بعد حادثة دنشواي ونما النشاط السياسي وظهرت الأحزاب المصرية حزب الأمة والحزب الوطني وحزب الإصلاح على المبادئ الدستورية ، ومع هذا ظهر لنا خلاف ديني كان ميدانه صحيفتي مصر

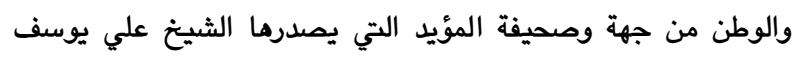
ويعض الكتابات التي تصدرما صحيفة اللواء لسان حال الحزب الوطني من جهة أخرى ، وفي 22 ايار1908 نشرت صحيفة مصر مقالا تهاجم فيه كل من وطأة أقدامه مصر من بداية الإسلام الى تلك الفترة وماجمت

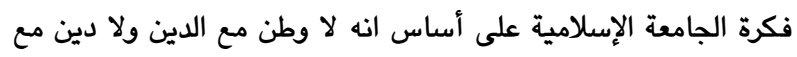

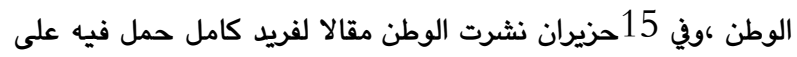
التاريخ الإسلامي في مصر،ونشر عبد العزيز جاويش في اليوم التالي مقالا" الإسلام غريب في بلاده" تكلم فيه بأقسى ما يمكن ان يكتب في موضوع كهذا، وكان للمقال وقع شديد على المسيحيين، وردت صحيفة الوطن ونعتت جاويش بالتونسي الدخيل ووصفته بالحاقد ويلقي سمومه بين صفوف المصريين.(113) دعت اللجنة المركزية للحزب الوطني المى إدانة جاويش لأنه " اعتدى على

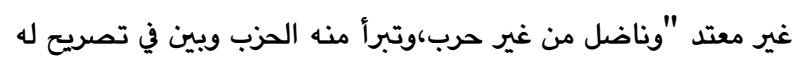

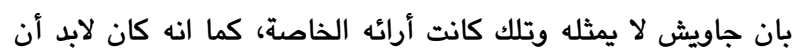
يتعامل مع الموقف بأسلوب أكثر حكمة لأنه لم يفرق بين الصديق

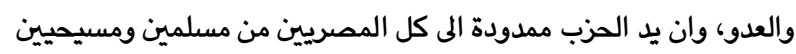

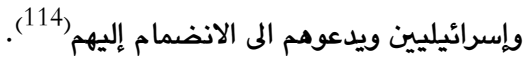
بدا الأقباط يتباعدون عن خطى الحزب الوطني ومنهم سينوت حنا احد أعيان وتجار أسيوط، وكان صديق مصطفى كامل وتباعدت خطاه عن بن الحزب بعد وفاة مصطفى كامل بسبب ضعف القيادة الجديدة المتمثلة بمحمد فريد وارتفاع صوت عبد العزيز جاويش " الذي توجس الأقباط خيفة منه بدأت ظهور بوادر للتقارب بينه وبين سعد زغلول(115) منذ هندين أن التقيا عام 1908 (116) أما مصطفى كامل فقد أدرك بان الوقت غير مناسب للمشادات

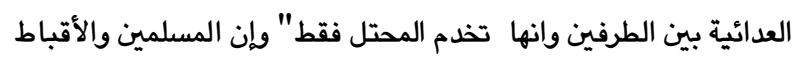

شعب واحد مرتبط بالوطنية... والأقباط إخوة لنا في الوطن"(117). ساءت العلاقة بين الأقباط وخلفه محمد فريد الذي استقبل وزارة بطرس غالي بفتور تام ولم يعبر بكلمة أسف واحدة بسبب اغتياله ولما فقد كل أمل بالأقباط وانسحابهم من الحزب تراجع عن موقفه،وأكد أن القاتل لم يكن مدفوعا بدوافع دينية بل بدوافع الوطنية(118).

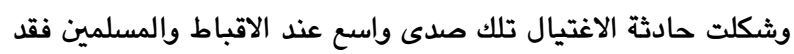
عقد الأقباط مؤتمر عام 1911في مدينة اسيوط وطالبوا فيه بالحقوق المدنية الكاملة للاقباط مع ضرورة مراعاة مبدا المساواة لجميع 
اما ما يثير الدهشة في مناقشات المؤتمرين القبطي والمصري هو عدم وجود أية معارضة لسلطة الاحتلال أو أي انتقاد لسياستة او مطالبة بريطانيا بتنفيذ وعودما للحركة الوطنية ، في حين ان طابع المؤتمرات في ذلك العهد كان توحيد الصفوف الوطنية لمقاومة الاحتلال ،وقد كسبت مصر من تلك المحنة نجاحا جديدا وهو الوحدة الوطنية وتوحيد صفوفها من جديد، وفي المقابل خسرت خسارة كبيرة إذ أصبحت المسائل السياسية المهمة في الدولة تأتي في المرتبة الثانية بعد الخلافات الدينية،وخرج الاحتلال من ذلك سليما، اذلم تقحمه الصحافة المصرية لا القبطية ولا الإسلامية وانتهى المؤتمران الى قرارات اتخذت لم يشر واضعوما الى اي احتجاج على سياسة المحتل او المطالبة بالدستور للبلاد،وانتهى الى قرار مهم وهو استحالة قسمة الحياة السياسية في مصر بـ

وفيما يتعلق بكل من اخنوخ المصري زعيم الطائفة الانجيلية في مصر والذي اسس الحزب المصري من عدد من الاقباط ودعا فيه الى استقلال مصر بالتعاون مع صديقتها بريطانيا،وعبد العزيز جاويش والذي تبرا منه الحزب الوطني بسبب كتاباته التي تجاوزت العقل واثارة المسلمين ضد الاقباط،فان الراي العام المصري كان يمقت كلا من الطرفين والتي انتصرت بالنهاية كفة العقلاء ولكن لم يقم اي منهما بالطعن في دين الاخر واقتصرت خطاباتهم على مهاجمة الفئة الأخرى (133). في عام 1911 كتب اللورد جورست يقول بان" القبطي ناجح ولكنه ليس محبويا فلو عهدت اليه وظيفة تنفيذية عليا فسوف يجد مجموعة من الناس مدفوعين بمشاعر العداء نحوه وسوف لا يتوقع منهم تعاونا او طاعة سريعة" (134). ويذكر الخديوي عباس بانه" يمكنني ان اقول ان الرئيس الوحيد لمجلس النظار والذي عمل بدون توقف وفي اثناء كل الوقت الذي كان ناظرا فيه ومن اجل خدمة بلاده،وامير البلاد هو بطرس غالي ...ولم يرتكب سوى خطا واحد هو دنشواي....وكان تفكيره المبتكر والخلاق

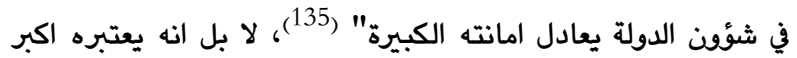
رجال السياسة في مصر والشرق واقدر رجال زمانه (136)

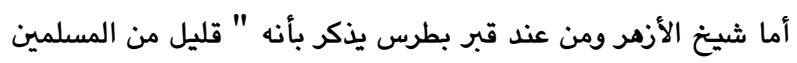

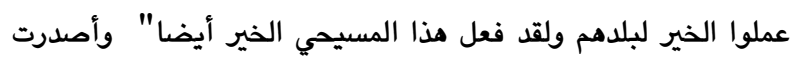
المؤيد جريدة الشيخ علي يوسف ملحقا وصفت الاغتيال بالحدث المحزن ووصفت اللواء جريدة الحزب الوطني الحاث بالخطير(137)، والأمر المهم الذي يتضح لنا انه بعد ثمان سنوات من حادثة الاغتيال

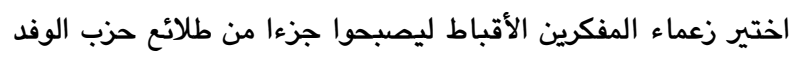

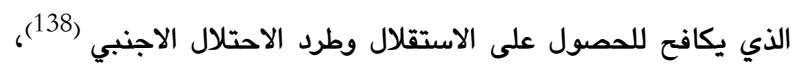
وابرز سمة لهذا العصر هي ان الوحدة الوطنية التي أصبحت جزءا مقدسا لا يستطيع احد العبث به واقتنع الجميع ان الدين لله والوطن للجميع وانهم مصريين اولا.
الشبيبة الإسلامية والشبيبة المسيحية،لانه احتفال لدين شريف مبدؤه ان محبة الوطن من الايمان،وعلى هذا المبدا اقول بانني مسلم ومسلم،مهما قيل وقال عن تقاطعنا وتدابرنا فنحن اخوان في الوطنية،اذا حدث خلاف بين مصريين ومصريين فلا يعد ذلك دليلا على عدم وجود اخاء وانما هو من مستلزمات الحياة " وقد ردت صحيفة الوطن عليه واتهمته بالذيانه وشبهته بيهوذا الاسخريوطي(126). كان أول انشقاق في المجتمع القبطي نفسه حادثة اغتيال الوزير بطرس غالي فبعد تلك الحادثة، ويعد انعقاد مؤتمر اسيوط اعلن بعد فترة وجيزة من حادثة الاغتيال اي بعد شهرين نظمت مجموعة من المسلمين البارزين ما أسموه "المؤتمر المصري" في مصر الجديدة وأشاد بالورداني كبطل من قبل القوميين.وفيه رفض مطاليب الأقباط من التمييز وتأكيد استنتاجهم أن الدين الرسمي للبلاد الإسلام هو دين الأغلبية، ويذلك فان المؤتمرات القبطية والمؤتمرات و المصرية شهدت نقطة تحول مامة في الدولة المصرية لتبرز الى الوجود لأول مرة مسالة الأقلية والأغلبية (127). ويقال بان الخديوي أراد ان يورط جورست ليلمح للأقباط بعقد مؤتمر لعرض مطلبهم وان بريطانيا سوف تساعدهم فتبادل كل من الأقباط والبريطانيين الاتهامات وأثاعوا البريطانيون بان الأقباط بعد احتلال

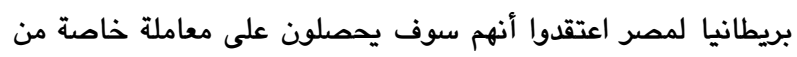
بريطانيا وان الأخيرة سياستها عدم التفرقة بين الطرفين على الرغم من أنها استخدمت سياسة فرق تسد، بينما الأقباط أنكروا ذلك وأرادوا المساواة بين المصريين فقط، على اعتبار بأنه لا توجد ادلة على عدم كفاءات الأقباط في تولي المناصب الإدارية في البلاد(128). شهدت الفترة 1908-1911م قمة الخلافات بين الطرفين ولكن ما يلاحظ على الجدل بينهما أنهما كانا يصدران من أرضية فكرية واحدة تاريخا وتكوينا نفسيا مشتركا ،فمن هاجم المسلمين عن سوء معاملتهم للقبط وأوغل في الشكوى وما يسموه بالاضطهاد كان يقارن الحاضر

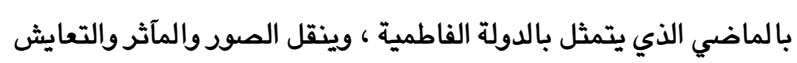
بين الطرفين في نفس الصورة،مع تردديهم للأحاديث النبوية التي توصي بأهل الذمة(129). ومما اثار الشقاق خطاب الرئيس الامريكي الاسبق تيودود روزفلت(1909-1901)، الذي ذكر في محاضرته التي القاها في الجامعة الاهلية المصرية لعام 1910 عن مقتل بطرس غالي محاولا اثارة النعرات الطائفية "ان مثل هذه الامم تكون خطرا على نفسها لانها لم تنم فيها الصفات التي تمكنها من الانتفاع بالدستور "(130) اما كتشنر 1911-1914 فانه لم يكن مؤمنا بنظام الأحزاب بالشرق لأنه كان يعتقد بان له تأثير مدمر على المجتمع ، اما الروح الحزبية بالنسبة لهم ويقصد(الأمم الشرقية)، فهي مثل الشراب المسكر للوطنيين الأفارقة غير المتحضرين(131). 
بدأت بوادر الوحدة الوطنية تظهر بين الطرفين وتذكر صحيفة الوطن

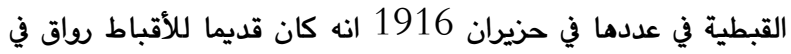
الازهر يتلقون فيه العلوم الشرعية والمنطقية،وابرز من كانوا قدرسوا فيه في تلك الفترة ميخائيل عبد السيد صاحب جريدة الوطن اذ درس في الازهر ثم انتقل الى دار العلوم، وفرنسيس العتر الذي كان يحضر جيدر دروس الشيخ محمد عبدة منذ عام 1902(148). وعندما علم الاقباط اثناء تواجدهم في نادي رمسيس القبطي اثناء عمل الوفد لجمع التوكيلات وعلمهم بسعد وتوجهه الليبرالي شكلوا وفدا لمقابلته وقد رحب بالوفد المكون من فخري عبد النور وويصا واصف وتوفيق اندراوس الذي قال لسعد "ان الوطنية ليست حكرا على المسلمين" سر زغلول بسماعه لذلك ورحب بانضمامهم الى الوفد (149 لـورئ. واستقر الراي على ترثيح واصف بطرس غالي ليكون ممثلا عن الاقباط في الوفد(150)،ثم انضم للوفد عام 1918 سينوت حنا عضو الجمعية التشريعية وجورج الخياط من كبار اعيان اسيوط الذي سال زغلول عن عن مركز الاقباط ومصيرهم والذي رد عليه الاخير مطمئنا

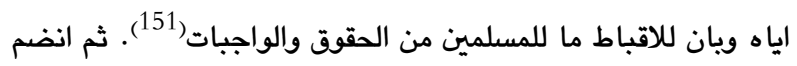
اليهم سينوت حنا وجورج خياط وحلفا اليمين في جلسة 2 كانون الاول 1918 وسافر سينوت بعدما مع اعضاء الوفد الى باريس( 152).

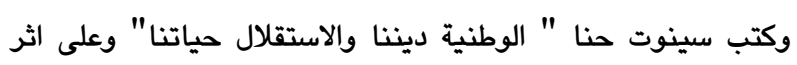
تصريحاته تلك التي مثلت الاقباط قامت السلطات البريطانية باعتقاله وفرض الاقامة الجبرية علية،ليتم بعدها اعتقال العديد من أعضاء الوفد من المسلمين والاقباط ايضا ابان الاعوام 1918-1919(153)، مذه بهديه المدة التي بدأت موازين القوى تتغير مع انتهاء الحرب العالمية الاولى واخذت القوى الاستعمارية وفي مقدمتها بريطانيا بناء نظام عالمي جديد يتناسب مع الوضع الدولي الجديد والذي هيئ له في مؤتمر فرساي لعام

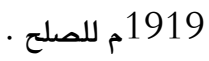
ويناء على ذلك فقد اجتمعت القوى الوطنية المصرية وقرت المشاركة

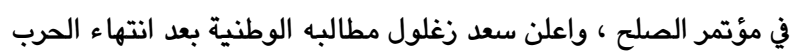

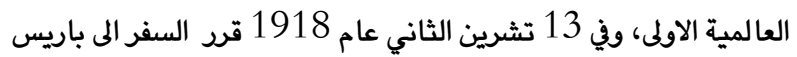

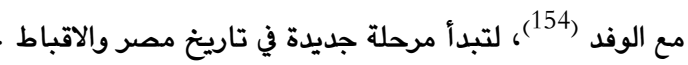

\section{6. الخلاصة والاستنتاجات}

بعد ان كان الاقباط ولقرون عديدة يتبوؤون المراكز الادارية فقط بدأوا يشهدون تغييرا كبيرا في وضعهم السياسي وذلك لسبب رئيسي مهم وهو سـياســة التسـامح التي انتهجها الوالي محمد علي لبث روح المساواة والمواطنة بين مكونات المجتمع المصري ، بعد ان هذا الوالي بتجاوز كل القيود الدينية والدنيوية التي فرضـــها المجتمع المصــري على غير المسـلمين لاثــاعة الحرية والمسـاواة في النسـيج الاجتماعي المصــري،ومن ثم بث روح العيش والحياة المشــتركة بين فئاته، ولم

\section{5.الأقباط إبان الحرب العالمية الأولى( 1918-1914)}

بعد تجاوز الازمة الطائفية كانت ظروف التوجه نحو الوحدة الوطنية اقوى من ظروف التفرقة والتي بدات بنهب المستعمر لخيرات البلاد والتاثير على اقتصاد البلاد والتي طالت المسلمين والاقباط الى جانب ظروف الحرب العالمية الاولى وماتعرض له الفلاح والتاجر والموظفين والضباط ، فضلا عن تنامي البرجوازية المصرية والتي اقتنعت بأهمية

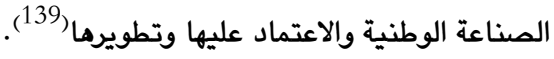

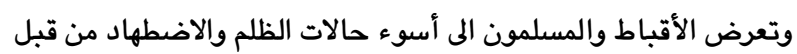
الاحتلال البريطاني فتألفت مشاعرهم وتهيأت أذهانهم للاتحاد والتضامن مع بعضهم للتخلص من عدوهم المشترك الاحتلال البريطاني وانتهى الدور التاريخي للحزب الوطني في قيادة الحركة الوطنية واختفى بعض زعماء الطرفين المتعصبين كعبد العزيز جاويش الذي كان يكتب في جريدة اللواء وجندي إبراهيم صاحب جريدة الوطن ،واختفى الاعتقاد السائد للطرفين بتلقي الدعم والحماية من الدولة العثمانية كونها مركز الخلافة الإسلامية بالنسبة للمسلمين او الاستعمار البريطاني كونه المنقذ بالنسبة للأقباط، وفي نفس الوقت اشتد التيار الليبرالي والذي ولد في رحمه زعماء ثورة 1919،وكل هذا كان له تأثير ايجابي للطرفين للاندماج مع بعضهم والوحدة الوطنية(140).

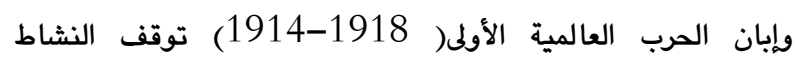
السياسي بسبب إعلان الإحكام العرفية ،وحل المجلس التشريعي،فكان

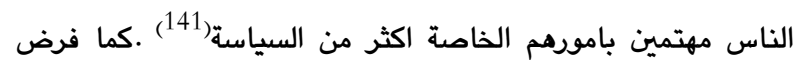
التجنيد الاجباري للمصريين وتم تجنيد العديد من المصريين لعملية النقل بالجمال في سوريا وفلسطين والى الحماية في السودان وغيرما(142).فضلا عن تسخير كافة موارد مصر لصالح بريطانيا وجيشها ،واصبحت الصحف والحركة الوطنية تفيض بالدعاية عن حق تقرير المصير وعن حقوق الشعوب الصغيرة وعند نهايتها أعلن رشدي باشا رئيس ونراء مصر بالذهاب الى لندن وعرض مطلب الاستقلال

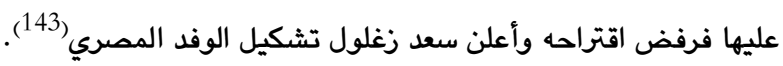
تاسست خلال الحرب الجمعية التشريعية لعام 1914 والتي كانت مكونة من 66 عضوا منتخبا و17 عضوا معينا (144)، والتي قامت على دستور 1913 وكان فيها سعد زغلول عضوا منتخبا وسينوت من حنا عضوا معينا ومعه كل من قليني فهمي وكامل صدقي ومرقس سميكة وعندما ثار خلاف مبكر ايضا بين سعد المنتخب وبين عدلي الوكيل المعين انحاز سينوت الى سعد ( 145)، كما اختير يوسف وهن وهبة المنية وزيرا للمالية في وزارة حسين رشدي باشا ولتي تشكلت في 15 نيسان 1914، واستمر وزيرا للمالية بعد ان اصبح السلطان حسين كامل سلطانا على مصر على عهد وزارة حسين رشدي باشا الثانية 9 كانون الاول 1914 ،ومن ثم وزارة حسين رثدي باشا الثالثة على عهد الملك فؤاد (146) لانه جرى العرف منذ عام 1883 على تعيين قبطي واحد 183 في كل وزارة (147). 


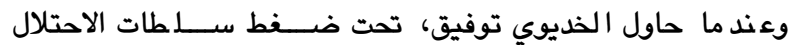
البريطاني، إلى التوقف عن العمل مع الدسـتور، تم تأسـيس أول حزب

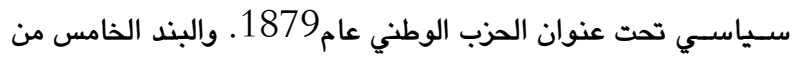

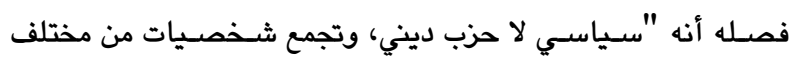
الطوائف، وكان بعض الأقباط والبعض الآخر اليهود، لأنه لم ينظر إلى

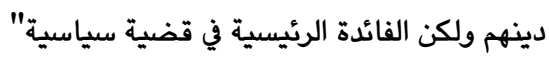

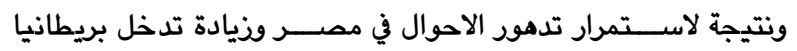

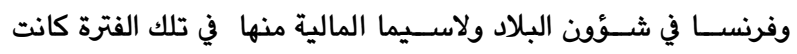
ولادة حركة وطنية في مصـر يسـاندها العسكريون الذين مثلوا غضـبة وطنية على الاتراك والجراكسـة ، فاندلعت الثورة الوطنية اخيرا بزعامة احمد عرابي.التي ذشات تحت شعار "مصر للمصريين "، وخلال تلك الفترة شــعرت بريطانيا رغم قوتها بالتهديد ألا ومو قيام ثورة وطنية ضدما،وقد لجأت إلى أساليب مختلفة لسحق الوحدة الوطنية عن طريق فصـل الأقباط والمســلمين والتعامل مع الأقباط على أسـاس عرقي لعزلهم عن الحركة الوطنية التي تحاربها تفتيت المؤســـــــات الدينية

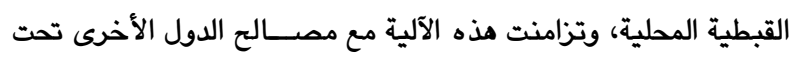
ذرائع دينية: حماية فرنســا الكاثوليك، وكان شـــار روســيا حماية الأرثوذكســـــة، والولايـات المتحـدة الأمريكيــة الترويج الإنجيليــة البوتستانتية.

ومع بداية القرن العشـــرين بدأت الأفكار تتجه نحو الوحدة الوطنية

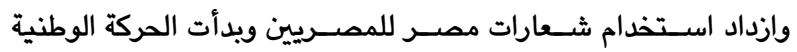
بجهودها التي أخذت تتجه نحو الوحدة الوطني. إن المثقفين المســـيحيون وتبعهم المســـلمون وكلهم علمانيون رفعوا أصواتهم يرددون فيه أن الوقت غير مناسب للرابطة الإسلامية وكانت الشـعارات مناسـبة لظروفها وكانت لا تعوزما التبريرات لان العثمانيين المسـلمون بالأمس لم يسـطيعوا وقف الزحف الأوربي على الأراضي العربية.

اتسـعت مشــاركة المسـيحيين عموما في الحياة السـياسـية المصـرية ودخلوا الأحزاب التي بدأت بالتأســـيس منذ العقد الأول من القرن العشرين فا شترك اثنان منهم في تأ سيس حزب الإصلاح على المبادئ الدستورية والذي تزعمه الشيخ علي يوسف ، كما انضم مرقس حنا و ويصا واصف الى الحزب الوطني الذي أ سسه مصطفى كامل،وعندما تأسـس حزب الأمة عام 1907 ضـمت جمعيته 16 من المسـيحيين من بين أعضـائها البالغ 113 عضــوا،وأسـس اخنوخ فانوس الحزب المصري،ولكن الحزب قام على أسس طائفية وعلى أساس التعاون مع المحتل لذلك لم دشهد إقبالا عليه من قبل المسيحيين إيمانا منهم بان مصيرهم جزء لا يتجزأ من مصير بقية المصريين. وهنا شرعت سلطات الاحتلال البريطاني في تنفيذ سيا ستها لأحداث شـقاق بين المصـريين، وكان في مقدمتها توظيف الاختلاف في العقيدة الدينية بين مسلمي مصر وأقباطها، وذلك لكبح الحركة الوطنية وإثارة
يجد صـعوية في ذلك اذ وجد اندماجا تدريجيا في شــصــية المجتمع المصري بين مسلميه واقباطه. كان عهد الخديوي إسماعيل قد شـــهد اندماجا كاملا بين المســلمين والأقباط لاسـيما بعد اعتراف الدولة منذ عهد الوالي سـعيد بالتسـاوي في الحقوق والواجبات الوطنية مســـاواة تامة ،وقد تجلى ذلك في العام 1866 الذي شـهـد إطلاق الحياة البرلمانية في مصـر من خلال إنثـاء المجلس الخديوي او مجلس شـورى النواب (اسـتشـاري). ووفقا لتلك

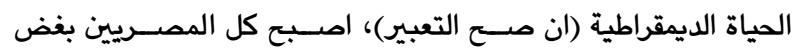
النظر عن دينهم لهم الحق في التمتع بالحقوق السيا سية" والترشيح الى هذا المجلس وقام بدعم المدارس القبطية ماليا، وقرد علانية المسـاواة بين المسيحيين والم سلمين ، وذلك بتر شيح الأقباط لانتخاب أء ضاء مجلس شورى القوانين. ففي أول برلمان مصري منتخب سنة 1866م دخل الأقباط الانتخاب

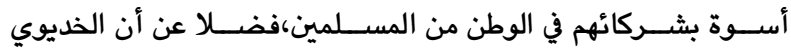

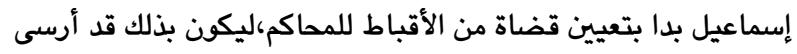
د عائم الجامعة الوطنية المبذية على أســــاس المســــاواة والعدالة الاجت ماءية، ولينطلق مذها الأق باط ومن ثم المســـلمون المثقفون للدعوة الى التخلص من الســـيطرة العثمانية وســـيادتها على مصــر والبحث عن الاستقلال التام للبلاد في إطار الحركة الوطنية . . وقبل تشكيل المجلس تقرر ترشيح الأقباط في مجلس الشورى والدليل على ذلك فقد اجمع نواب المجلس بموافقتهم على قبول دخول أبناء

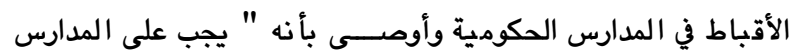

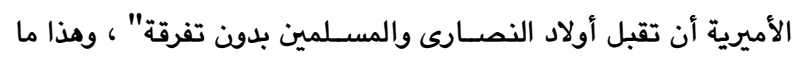

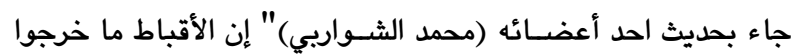
عن كونهم أبناء الوطن ، ولذلك يجب أن يكونوا ضـــمن المدارس التي تعمل با لمديريات( المحافظات) ولا يكونوا خارجا عذها متى أرادوا

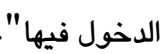
وقف النواب في البرلمان وقفة رجل واحد عام 1879 مع الخديوي في محنته المالية لذلك وقف بالاجماع وقفة وطنية ورفضــا مبدا تسـوية م شاكل مـ صر بإعلان إفلا سها وهو موقف وطني لا غبار عليه بسبب تصـاعد الأزمة السـياسـية في البلاد قام خلالها مجلس شـورى النواب إنهاب أثناء انعقاد الدورة الثالثة 1879 ويرئاســــة احمد رشـــيد بإرســال عريضــة للخديوي والاحتجاج المالي الذي يرفض إعلان إفلاس مصـر إلا أن وذارة توفيق أوصـــت بحل مجلس النواب وانتهاء مدته وعدم تحديد موعد للانتخابات الجديدة . واكد رئيس الوزراء المصري اسماعيل باشا في نهاية سبعينيات القرن التاســع عشــر، قالها للوالي التركي وذكرها المؤرخ القبطي جبرائيل

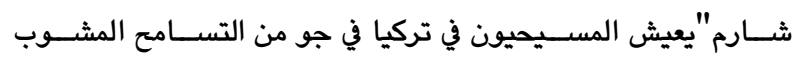

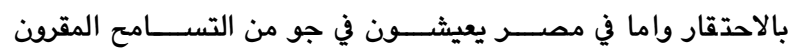

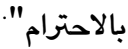


85 (9) ويصا، المصدر السابق،ص

(10) جاك تاجر،اقباط ومسلمون من الفتح الاسلامي حتى عام 1922، ص236.

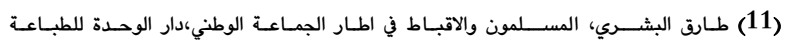

والنشر،بيوت، 1982، ص30.

(12) Azmy \& Saied,o.p,Cit,p108.

(13) سهير حلمي،أسرة محمد علي،مكتبة الأسرة،القاهرة، 2003، ص208.

\begin{tabular}{r|r|r|r}
\hline The year & The Copts & The number of the Egyptians & Source \\
\hline 1879 & 331,235 & $10,016,917$ & Census \\
\hline 1907 & 661,692 & $11,185,478$ & Census \\
\hline 1917 & $1,025,852$ & $12,717,861$ & Census \\
\hline 57 & & & \\
\hline
\end{tabular}

(14)محمد إبراهيم المرشدي،عروبة مصر وأقباطها،دار الشرق الأوسط للنشر،القاهرة، 1993، ص57.

(15) سميرة بحر،الأقباط في الحياة الســياسـية المصــرية،مكتبة الانجلو المصـرية، القاهرة،1979،

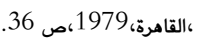

(16) ســلِمان شـــفيق، الأق باط بين الحرمان الكنســي والوطني، دار الأمين للطباعة والنشــــر

والتوزيع،القاهرة، 1996، ص 40.

(17) تيموثي ميتشـل، اسـتعمار مصـر، ترجمة بشـير السباعي واحمد حسـان ،مركز مدارات للابحاث

والنشر،القاهرة ، 2013، ص 143.

(18) لمعي المطيعي،موسوعة هذا الرجل من مصر ،ط2،دار الشرقق،القاهرة، 1997،ص194

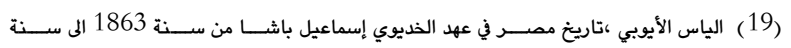
1879،مكتبة مدبولي،ج1،القاهرة،د،ات، 69" جمال بدوي،مدمد علي وأولاده، مكتبة الأســرة،

$$
\text { القاهرة ، 1999، ص م } 147 .
$$

(20) نوبار با شا: ولد في مدينة أزمير (الواقعة في غرب تركيا) سنة1825م،وهو ارمني الجذسية، أرسل منذ صغره إلى أوربا،فتعلم في مدارس سويسرا وباريس،وجاء إلى مصر سنة1842.وكان والده بوغوص بك مستشـاراً للوالي محمد علي،شـارك نوبار مع الوالي إبراهيم باشـا في حملته على سـورية واستانبول مستشاراً للأخير، وانعم عليه الوالي عباس الأول بلقب بك ، ثم عينه وزيراً مفوضاً في فينا سنة 1853، فمديراً للسـكك الحديدية ســة 1854، ثم عينه الخديوي إسماعيل وزيراً للخارجية ســة 1866،إلى أن تولى رئا سة الحكومة لعدة دورات، "نوبار باشا"، مجلة المقتطف،ج2، السنة الثالثة والعشرون، القاهرة، شباط، 1899، ص صدم 101- 103. (21) انطونيوس الانطوني،وطنية الكنيســـة القبطية وتاريذها من بعد الاباء الرســل حتى الانتداب البريطاني على مصر،ط2، المكتبة القبطية،القاهرة، ص ص 389-390.

$$
\text { (22)ويصا،المصدر السابق، ص } 90 .
$$

(23) عبد الرحمن الرافعي، عصر إسماعيل، ج2، ص ص 83084، رياض سوريال، المجتمع القبطي في القرن 19، مكتبة المحبة ، القاهرة، 1981، ص52.

(24) سـليمان نسيم، الاقباط والتعليم في مصـر الديثة،منشـورات اسقفية الدراسـات العليا اللاهوتية

والثقافة القبطية والبحث العلمي،مطبعة نهضة مصر، القاهرة،د.ت، ص73

(25) زاهر رياض، المسيحيون والقومية المصرية، دار الطباعة القومية بالفجالة، 1978،ص 100.

$$
\text { (26) ويصا المصدر السابق، ص 90" تاجر،المصدر السابق، ص237. }
$$$$
\text { (27) الانطوني،وطنية الكنيسة...، ص388. }
$$

الفوارق الدينية وحق الأغلبية في تولي المنا صب السيادية، ونجحت في الوقت نفســــه في اســــمالة بعض أعيان الأقباط إلى جانبها.وتعد

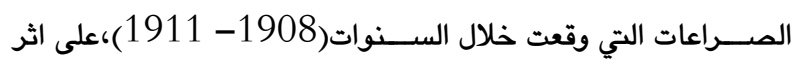
اغتيال بطرس غالي نموذجاً للصـراعات الطائفية التي أدارتها سـلطة أجنبية، والتي أدت إلى الاحتقان الدموي، والتي ادت بالنهاية الى حل المشكلة بين ابناء الوطن وبصورة سلمية لأسباب منها انتشار فكرة المواطنة المصــرية وانتشــار افكار المســاواة والوحدة بين كافة ابناء الوطن الواحـد، وظهر ذلك جليـا بعـد انتهـاء الصرب العـالميـة الاولى 1914-1918 وانضــمام الاقباط الى مواطنيهم المســلمين في حزب

\section{1. الهوامش والمصادر:}

(1) الاقباط : كلمة قبطية تعني مصـرية، وهي ماخوذة من الكلمة اليونانية" Ciptos " وقد حرفت في اللغة الانكليزية الى " Copts " وحورت في اللغة العربية الى " قبط" وكان كل المصـريين أبناء الفراعنة قبل دخول المسـيحية والإسـلام الى مصـر يسـمون القبط، وبعد دخول الإسـلام دعيت كلمة قبطي على المســـيحي المصــري وليس على كل المصــريين ومن هنا اخذ المســـــيون المصــريون اســم

الأقباط،للتفاصيل ينظر، زكريا بطرس ،التعريف بالكنيسة القبطية الأرثوذكسية،د.م،د.ت ،ص 7، J. D. Pennington "The Copts in Modern Egypt" Middle Eastern Studies, No2, Vol 19, London, April, 1982, P 160“

$$
\text { والجدول الاتي يبين نسبة الاقباط الى المسلمين في مصر : }
$$

Noha Osman Azmy \& Louay Mahmoud Saied, A New Vision of the Copts of Egypt: State Policy and Inner Difficulties (1948-1957),In: Light of US State Department Documents, Kyoto Bulletin of Islamic Area Studies, 8 March 2015, p106.

(2) Jacquse Tagher,Cristians in Muslim Egypt An Historical Study of the Relations between Copts and Muslims from 640 to 1922, Oras Verlag Altenberge ,1998, p197.

(3) محمد سـعيد ابن محمد علي: ولد في الإسـكندرية ســـة1822م ، كان رئيسـاً للبحرية ، وتولى حكم مصر بعد ابن أخيه عباس الأول في تموز1854م ، توفي ودفن في الإسكندرية سنة 1863، ينظر: محمد حســام الدين إسماعيل، مدينة القاهرة من ولاية محمد علي إلى إسماعيل 1805- 1879، دار الآفاق

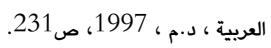
(4) زخـاريـاس الانطوني، البـابـا كيرلس الرابع (ابو الاصــلاح)،دار الطبـاعـة القوميـة بـالفجـالـة

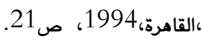
(5) حنا فهمي ويصا، اسيوط حدوته عائلة مصري،مركز الاهرام، القاهرة، 1996،ص 85. (6) عزيز ســور يال عطية ،تاريخ المسـيحية الشـرقية،ترجمة اسـحاق عبيد، المجلس الاعلى للثقافة،

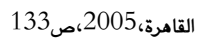

(7) Iris Habib el Masri, The Story of the Copts ,Newberry,California, Vol 2,USA,1982, p332.

(8) Saad Eddin Ibrahim ET AL, , The Copts Of Egypt, Printed In The UK On Pleach, London ,1996,P6.๑ 
(44) " وثائق" الحزب الوطني المصـري" مجلة الطليعة، (القاهرة)،ــباط ، 1965. ص ص 148-

$$
\text { 149، طارق البشري، المسلمون والاقباط، ص47. }
$$

(45) احمد عرابي : ولد في 31 آذار 1841 في قرية هرية رزنه (إحدى ضـــــاحي تل بســـ في محافظة الشـرقية)، بدأ تعليمه في كتاتيب القرية ، حيث تعلم مبادئ القراءة والكتابة، وتعلم مبادئ الحسـاب على يد الصــراف ميخائيل غطاس . التحق بالجامع الأزهر ســنة 1849، ليتعلم فيه حفظ القرآن والفقه والتفسير واللغة العربية ، التحق بسلك العسكرية سنة 1854، وتدرج في المناصب فوصل إلى رتبة أميرال سنة 1879 ، ثم أصبح وزيرا للحربية وقاد الثورة العرابية ، توفي سنة 1911 ، للمزيد من التفاصيل، ينظر: محمود متولي، ســلســلة رواد الحركة الوطنية المصــرية في التاريخ الحديث ،احمد عرابي، وزارة الإعلام، د. م ، 2008 ، ص ص15- 16،حنا، المصدر السابق، ص22. (46) الانطوني، وطنية الكنيسة،ص 392. (47) احمد حسين ،موسوعة تاريخ مصر ،مطابع دار الشعب ، ج3، القاهرة ، د.ت، ص19. (48) عطية ،المصدر السابق، ص133. (49) نقلا عن: حلمي، اسرة محمد علي،ص ص 238-239.

(50) D.A. Farnie, East and West of Suez 1854-1956, Ciarendon Press, Oxford, 1969, P. 283.

(51) Darrell I. Dykstra, Egypt in the Nineteenth Century-The Impact of Europe upon Anon-Western Society, Michigan Ann Arbor, N.B, 1979, P.P. 20

(52) عبدالله النديم: عبدالله بن مصـباح النديم: ولد في مدينة الإسـكندرية ســة 1845.ونشـا في أسـرة فقيرة الحال، تعلم في كتاتيب المدينة نفسـها ، دخل مدرسـة جامع الشـيخ إبراهيم ســة 1855 ليلتحق بعدها بالجامع الأزهر حيث تعلم علوم الفقه والنحو والصـرف، أسس جريدة الطائف، وكتب مذكراته عن حوادث عصره في عهد الذيوي إسماعيل سماها " تاريخ مصر في هذا العصر" ، ينظر: علي الحديدي ، عبدالله النديم خطيب الوطنية، مكتبة مصر ، القاهرة ، دت، ص ص 30-40.

(53) محمد حمزة الدليمي ،الســيـاســــة البريطانيـة تجاه الحركة الوطنيـة في مصــر(1882-

1914م)،رسالة ماجستير(غير منشورة)مقدمة إلى كلية التربية،جامعة الموصل، 2007، ص88.

(54) أ.ل.بتشر، تاريخ الأمة القبطية وكنيستها، مطبعة مصر بالفجالة،ج4،القاهرة، 1907،ص 371.

(55) Wilfred Scawen Blunt, Secret History of the English Occupation of Egypt, T.Fisher Unwin ,London ,N.D,P 106.

(56) الأنبا ديوسقورس ، موجز تاريخ المسيحية،مج 1،ج2،مكتبة المحبة،القاهرة ، د.ت،ص535. (57) المطيعي ،المصدر السابق ،ص428.

(58) Saad Eddin Ibrahim ET AL, , The Copts Of Egypt,Printed In The UK 0n Pleach, London ,1996,P6.

(59) ادوارد ويكن،|قلية معزولة القصــة الدديثة لأقباط مصــر، ترجمة نجيب وهبة،هئية الدراســات

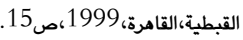

(60) طارق البشـري" مصـر الحديثة بين احمد والمسـيع"، مجلة الكاتب، العدد 111،القاهرة،حزيران،

$$
\text { 1970،ص ص 114-114. }
$$

(61) Lord Gromer, Modern Egypt, Vol 2 , London, N .D,p p 208-212.L

$$
\text { (62) نقلاً عن : تاجر،المصدر السابق، ص } 273 .
$$

(28) محمد ابراهيم المرشـدي، عروية مصـر واقباطها على طريق مشـروع حضــاري قومي، دار الشـرق

$$
\text { الاوسط للنشر، القاهرة،د.ت،ص240. }
$$$$
\text { (29) المرشدي، المصدر السابق، ص57. }
$$

(30) رمزي تادرسي، الأقباط في القرن العشرين، مطبعة جريدة مصر ج2.ص ص 81-82. (31) May Massaad, The Copts Of Egypt,Arab Center for Research \&Policy Studies,Doha,2011,p19

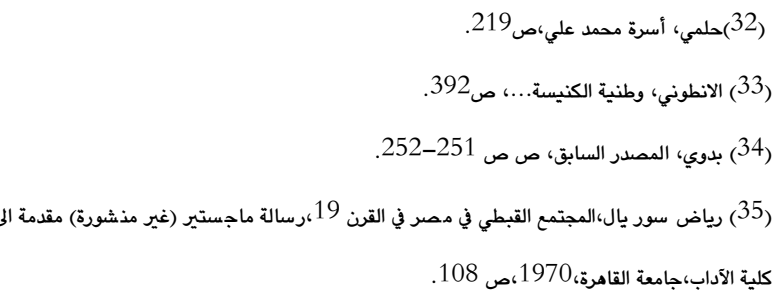

(36) بطرس غالي: ولد بالقاهرة ســنة 1846. تلقى تعليمه في مدرســة حارة السـقائين التي أنشــأها البطريرك كيرلس الرابع الملقب بابي الإصـــلاح، ثم في مدرســـة الأقباط الكبرى، اتقن اللغتين العربية والفرنسـية. وبعد تخرجه عمل مدرســاً في مدرســة حارة السـقائين، وعين مترجماً في مجلس التجارة في الإسكندرية عام 1867، وأصبح سنة1873 كاتب لوزارة العدل وفيها تدرج في المناصب إلى أن أصبح وكيلاً لها،وقف إلى جانب الثورة العرابية،ثم أصــــح وزيراً للمالية في وزارة رياض باشـــ الثالثة، فوزيراً للخارجية، ورئيسـا للوزراء.للمزيد من التفاصـيل(وتجدر الاشــارة هنا الى ان بطرس غالي هو جد الامين العام لامم المتحدة الاســـق بطرس بطرس غالي)، ينظر: "بطرس باشـــــالي"، مجلة المقتطف، ج4،

$$
\begin{aligned}
& \text { مج36،القاهرة، نيسان، 1910، ص ص 40- } 41 . \\
& \text { (37) ويصا ، المصدر السابق،ص162. } \\
& \text { (38) بدوي، المصدر السابق، ص ص 251-252. }
\end{aligned}
$$$$
\text { (39) تاجر، المصدر السابق، ص242، الانطوني، وطنية الكنيسة...، ص394. }
$$

(40) محمد توفيق ابن الخديوي إسماعيل : ولد ســــة 1852م. تعلم في القاهرة، وقد نشـــأ محدود الأفق، حيث لم يرسـله والده إلى الخارج لإكمال دراسته وإنما اكتفى بإبقائه بجواره ليتمرس بالأعمال ، وقد شـهـد عهده قيام الثورة العرابية (1881- 1882)، واحتلال بريطانيا لمصـر 1882، توفي ســـة 1892، ينظر: اطلال سالم حنا، الاوضاع الاجتماعية في مصر 1882-1914 دراسة تاريخية، اطروحة

دكتوراه( غير منشورة) مقدمة الى كلية التربية، جامعة الموصل،2013، ص19. (41) جمال الدين الأفغاني: ولد في مدينة سـعد آباد في كابل بأفغانسـتان، ولا نعرف مصـدراً لتاريخ نشأته، وعني والده بتربيته فاظهر ذكاء كبيرا ،تلقى علوماً كبيرة برع في اغلبها منها اللغة العربية وعلوم الشريعة والفلسفة وغيرها، سافر إلى الهند 1869،ومنها توجه لاداء فريضة الحج فاتجه إلى مكة المكرمة وقضى نحو سنة يتنقل في البلاد ويتعرف أحوالها وعادات أهلها حتى وفاته في مكة المكرمة عام 1857م ،ينظر:جمال الدين الافغاني ،القضــاء والقدر واصــول العقائد الاســلامية وامهات المســائل التوحيدية، المكتبة المحمودية،القاهرة، 1959، ص ص 3-4 - 3 -4. (42) محمد عبدة: وُلد عام 1849 بمحافظة البحيرة والتحق بالجامع الأحمدي بطنطا لتلقى علوم الفقه واللغة العربية،حفظ القران الكريم منذ صـفره ، انتقل عام 1865 للدراسـة في الجامع الأزهر وتخرج منه عام 1877،وبعد قيام الثورة العرابية عام 1882 نفي لثلاث ســـنوات اذ بقي عاما قي بيروت وانتقل بعدها الى باريس، عاد بعدها الى مصر ليدعو الى الاصلاح السياسي واصلاح اوضاع المراة المصرية، عين مفتيا على مصر عام 1899 حتى وفاته عام 1905، للمزيد من التفاصيل، ينظر:محمد عمارة، الاعمال الكاملة للامام الشيخ محمد عبدة،دار الشرقق،القاهرة، 1993، ص ص 23-24. (43) ويصا ،المصدر السابق، ص162. 


$$
\text { (89) (89) سليمال، المصدر السابق، ص110. }
$$

(90) زاهر، المصدر السابق ،ص ص 126-127.

(91) أبو سيف يو سف، الأقباط والقومية العربية، درا سة ا ستطلاعية ، مركز درا سات الوحدة العربية،

$$
\text { بيروت، 1987، ص } 117 .
$$

(92) نقلا عن ، بحر، المصدر السابق ،صروك3.

90 (93) تادرسي، المصدر السابق، ص

(94) زاهر،المصدر السابق، ص 142.

(95) (95) المصدر نفسه ، ص 140.

(96) نقلا عن ، يونان لبيب رنق، الأصـول التاريخية لمسـالة طابا،دراسـة تاريخية،مركز وثائق وتاريخ

مصر المعاصرة،القاهرة، 1983، صك36.

(97)(نقلا عن ، تادرسي، المصدر السابق، ص ص 96-97.

(98)سعد عبد الرزاق،بطرس غالي الاغتيال سياسي،صرح للنشر والتوزيع،القاهرة، 2010،ص 8.

(99) (99 المصدر نفسه، ص 8

(100) تادرسي، المصدر السابق، ص105.

(101) المرشدي، المصدر السابق، ص70.

(102) سعيد عبد الحكيم زيد،نصارى العرب وأقباط مصر،مكتبة وهبة،القاهرة، 2008،ص 61.

426 (103) المطيعي ،المصدر السابق ،ص4

(104)تقرير الحالة الدينية في مصـر ،مركز الدراســات السـياسـية والإســراتيجية بالأهرام، القاهرة ،1995،ص ص 147-148،فيف يان فؤاد، الاق باط والعمل الاجتماعي في مصــر اليات للاند ماج

والدضور المجتمعي، في: الاقباط في ـصر بعد الثورة ،تاليف: مجموعة باحثين،مركز اله سبار للدرا سات

والبحوث،دبي،2012،ص ص 69-70.

(105) مانن يوســف، البابا شــودة،حوارات في الايمان والثقافة والوطنية،ط2،دار الشــرق،القاهرة، 2001، ص63

$$
\text { (106) تادرسي، المصدر السابق،ص707) }
$$

(107) Saad Eddin Ibrahim ET AL, , The Copts Of Egypt, Printed In The UK On Pleach, London ,1996,P6.

(108)علي ليلة،دور الاقباط في بناء المجتمع الهصري في،الاقباط في مـصر بعد الثورة ، تاليف: مجموعة باحثين، مركز المسبار للدراسات والبحوث،دبي، 2012،ص ص 25-26.

$$
\text { (109) ويصا ، المصدر السابق،ص162. }
$$

(110)كمال مغيث،هتافات الثورة المصــرية ونصـــوصــها الكاملة،المجلس الأعلى للثقافة،القاهرة، .32 2014

(111)محمد حسنين هيكل،تراجم مصرية وغربية،مطبعة مصر، القاهرة،د.ت،ص 117. (112) عهدي مذكرات عباس حلمي الثاني خديو مصـر الأخير 1892-1914،ترجمة جلال يحيى،دار الشرق،القاهرة، 1993، ص ص 103. (113) البشري، المسلمون والأقباط، ص 69

$$
\text { (114) (114) المصدر نفسه، ص60. }
$$

(115) ســد زغلول:ولد عام 1860م بقرية ابيانة مركز فوه شمالي الدلتا ، حفظ القران الكريم وتلقى علومه الاولية بالقرية ، التحق بالجامع الازهر عام 1873م ، ثم التحق بمدرســـة الحقوق وتخرج منها ، اصـبح محراً بجريدة الوقائع الممـرية عام 1880م ، وفي آيار 1882م عين معاوناً بوزارة الداخلية .
(64) أ.ل.بتشـر، تاريخ الأمة القبطية وكنيسـتها،مطبعة مصـر بالفجالة،ج4،القاهرة، 1907، ص ص

$.391-390$

(65) Blunt, Wilfred Scawen,Secret History of the English Occupation of Egypt, , London, N.D,p125.

(66) Lord Lloyed,Egypt Since Gromer, Vol 2, London, 1923,p p 191192

$$
\text { (67) زاهر،المصدر السابق ،ص } 113 .
$$

(68) بتشنر،المصدر السابق،ص ص 390-391.

(69) تادرسي،المصدر السابق، ص83.

$$
\text { (70) }
$$

(71)الانبا بيشوي، نهضة الكنيسة القبطية منذ منتصف القرن التاسع عشر في: المسيحية عبر تاريخها

في الشرق،إصدار برنامج الدراسات والأبحاث ،مجلس كنائس الشرق الأوسط'بيوت، 2001، ،ص 776.

(72) مذكرات محمد فريد، تاريخ مصـر ابتداء من ســة 1891مسـيحية،القسـم الاول،القاهرة، 1975،

(73) نقلا عن: بحر، المصدر السابق، ص14.

(74) Pennington. Op. Cit. P.160.

(75) البشري، المسلمون والاقباط...،ص 59.

(76) Laure Guirguis, The Copts, the Nation, and the Revolution, Banting Postdoctoral Fellow, University of Montreal, Stanford University, 2013,P14

$$
\text { (77) السيد احمد فرج، جذور العلمانية،دار الوفاء للطباعة والنشر ،المنصورة،1985،ص49. }
$$

(78)Jason Brownlee, The The Violence Against Copts In Egypt, Carnegie Endowment for International Peace. All rights reserved,N.P, 2013, P20.

(79) مصــطفى كامل : ولد بحي الصـليبية بمدينة القاهرة في 14 آب 1874م ، التحق بعد تخرجه من الثانوية بكلية الحقوق بفرنسا وتخرج من جامعة تولوذ في تشرين الثاني 1894م ، اصدر في 18 شباط 1893م مجلة المدرسـة ، وي بداية شهـر كانون الثاني 1900م اصسدر صحيفة اللواء التي غدت لسـان حال الحركة الوطنية التي التفت حولها والتي انبثق عنها تأ سيس الحزب الوطني عام 1907م، الذي قاد الحركة الوطنية المصــرية ضـــــــــالال البريطاني مطالباً بالجلاء عن مصـر ، توفي في 11 شـــباط 1908م . الدليمي، المصــدر السـابق،ص50، للمزيد من التفاصـيل عن مصــفى كامل، ينظر: عبد الرحمن الرافعي ، مصــفى كامل باعث الحركة الوطنية ت تاريخ مصـر القومي من ســة 1892 الى ســة

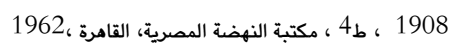
(80) عبد الرحمن الرافعي، مصطفى كامل باعث الحركة الوطنية، القاهرة، 1950،ص 408.

(81)سوريال، المصدر السابق، ص110 (82)زاهر ، المصدر السابق، ص ص 120-121. (83) المصدر نفسه ،ص 124. (84)البشري، المسلمون والأقباط...،ص64. (85) المطيعي ،المصدر السابق ، ص497. (86) حلمي،اسرة محمد علي ،ص255. (87) المطيعي ،المصدر السابق ،ص 187. 
(135) ادوارد ويكن، أقلية معزلة القصــة الحديثة لأقباط مصـر، ترجمة نجيب وهبة،هيئة الدراســات

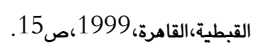

$$
\begin{aligned}
& \text { (136) عهدي مذكرات عباس، ص256 } \\
& \text { (137) تادرسي، المصدر السابق ،ص105 }
\end{aligned}
$$

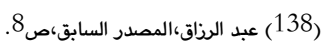

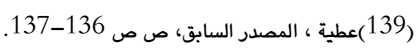

$$
\begin{aligned}
& \text { (140) ليلة ، المصدر السابق، ص ص26 -27. }
\end{aligned}
$$

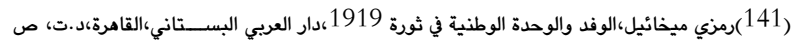
ص

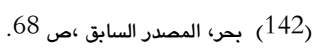

(143) Tom Little, Modern Egypt, Ernest Benu Limited,London,1967, $\mathrm{p} 70$.

(144) الينور بيرنز، الاستعمار البريطاني في مصر ،ترجمة احمد رشدي صالح" في احمد رشدي صالح:

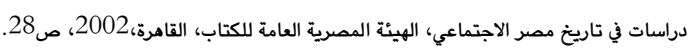
(145) حلمي،المصدر السابق،ص272. (146) المطيعي ،المصدر السابق ،ص190.

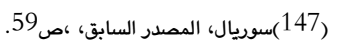
(148) ليلة ،المصدر السابق ،ص24. (149) المرشدي، المصدر السابق، ص60، البشري، المسلمون والاقباط.... ص43. (150) ميخائيل، المصدر السابق ، ص ص 124-125.

(152) المطيعي ،المصدر السابق ، ص641.

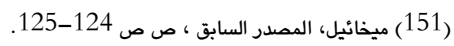
(152) المطيعي ،المصدر السابق ،ص190. (153) ميخائيل، المصدر السابق ، ص 69.

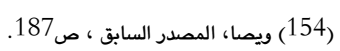

اشـترك في الثورة العرابية وفصـل من عمله بعد الاحتلال البريطاني ، اسـتأنف عمله بالمحاماة حتى عين قاضياً عام 1892م ، ثم مستشاراً وبعدها عين وزيراً للمعارف عام 1906م ، واتخذ موقفاً معارضاً من الاحتلال وسياسته ازاء التعليم ، قاد ثورة عام 1919م ، ثم انتخب رئيساً لمجلس النواب عام 1925م

$$
\begin{aligned}
& \text { ، توفي في } 23 \text { آب 1927م ، الدليمي ،المصدر السابق،ص51. } \\
& \text { (116)تاجر، المصدر السابق،ص250. } \\
& \text { (117) المصدر نفسه،ص250. } \\
& \text { (118) (المصدر نفسه،ص } 251 . \\
& \text { (119)عطية ، المصدر السابق، ص ص 136-137. } \\
& \text { (120) المطيعي،المصدر السابق،ص ص 188-189. } \\
& \text { (121) ويصا، المصدر السابق، ص179. } \\
& \text { (122) المطيعي ،المصدر السابق ، ص } 189 . \\
& \text { (123) البشري، المسلمون والأقباط، ص } 69 \text {. }
\end{aligned}
$$

(124) Pennington, Op. Cit, P.160.

(125) مصــفى الفقي، الأقباط في الحياة السـياسـية المصـرية مكرم عبيد ودوره في الحركة الوطنية،

$$
\text { ط2، دار الشرق، د.م، 1988.، ص } 41 .
$$$$
\text { (126) المطيعي ،المصدر السابق ،ص } 187 .
$$

(127) Azmy Saied, Op.Cit,p108.

$$
\text { (128) ويصا، المصدر السابق ، ص178. }
$$

(129)Saad Eddin Ibrahim ET AL, , The Copts Of Egypt, Printed In The UK 0n Pleach, London ,1996,P6.

(130) Magdi Guirguis \&Nelly van Doorn-Harder,The Emergennce of the Modern Coptic Papacy,the American University in Cairo Press,Cairo-New York,N,D,p p 99-100.

$$
\begin{aligned}
& \text { (131) احمد شفيق باشا" مذكراتي في نصف قرن ، مطبعة مصر، ج2، القاهرة،1936، ص } 912 \text {. } \\
& \text { (132) ويصا، المصدر السابق ، ص180. } \\
& \text {. } 68 \text { (133) بحر، المصدر السابق ،ص }
\end{aligned}
$$

(134) Saad Eddin Ibrahim ET AL, , The Copts,P6. $\square$ 


\title{
قويتى و رِوّلَّ وان يَّ سيايى ل مسرىٌ 1866-1918
}

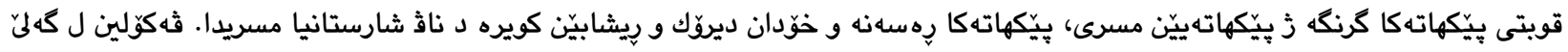

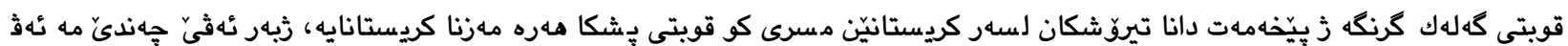

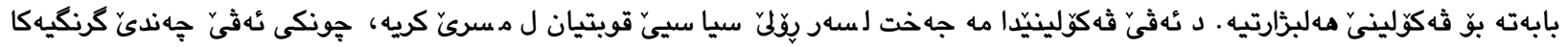

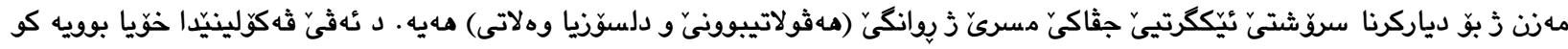

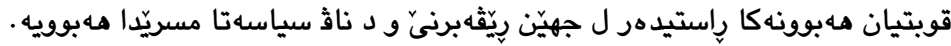

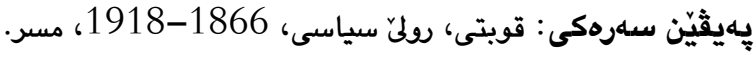

\section{COPTS AND THEIR POLITICAL ROLE IN EGYPT(1866-1918)}

\begin{abstract}
Copts is one of the essential communities of the Egypt ian .It also one of the original communities that has a history goes back to the Egyptian civilization .Because Egypt is a care of history. Civilization and religions it was of a great importance to shed the light on the Christians in Egypt as represented by the Copts. The study Focuses on the Copts Political role in Egypt forts essential importance to show the nature of the Egyptian Society that is unified by their citizenship and Home Loyalty This is well clarified as mentioned in this study by the real representation of the Copts at the Political and administrative sites.
\end{abstract}

Keywords: Copts, political role, 1866-1918, Egypt. 